Florida International University FIU Digital Commons

7-12-2012

\title{
Relative Role of Dispersal Dynamics and Competition in Niche Breadth
}

Robin N. Abbey-Lee

Florida International University, robin.abbey.lee@gmail.com

DOI: $10.25148 /$ etd.FI12080625

Follow this and additional works at: https://digitalcommons.fiu.edu/etd

\section{Recommended Citation}

Abbey-Lee, Robin N., "Relative Role of Dispersal Dynamics and Competition in Niche Breadth" (2012). FIU Electronic Theses and Dissertations. 674.

https://digitalcommons.fiu.edu/etd/674

This work is brought to you for free and open access by the University Graduate School at FIU Digital Commons. It has been accepted for inclusion in FIU Electronic Theses and Dissertations by an authorized administrator of FIU Digital Commons. For more information, please contact dcc@fiu.edu. 


\title{
FLORIDA INTERNATIONAL UNIVERSITY \\ Miami, Florida
}

\section{RELATIVE ROLE OF DISPERSAL DYNAMICS AND COMPETITION IN NICHE BREADTH}

\author{
A thesis submitted in partial fulfillment of \\ the requirements for the degree of \\ MASTER OF SCIENCE \\ in \\ BIOLOGY \\ by
}

Robin N. Abbey-Lee 
To: Dean Kenneth G. Furton

College of Arts and Sciences

This thesis, written by Robin N. Abbey-Lee, and entitled, Relative Role of Dispersal Dynamics and Competition in Niche Breadth having been approved in respect to style and intellectual content, is referred to you for judgment.

We have read this thesis and recommend that it be approved.

$\begin{array}{r}\hline \text { Evelyn Gaiser } \\ \hline \text { Michael Heithaus } \\ \hline \text { Joel Trexler, Major Professor }\end{array}$

Date of Defense: July 12, 2012

The thesis of Robin N. Abbey-Lee is approved.

Dean Kenneth G. Furton

College of Arts and Sciences

Dean Lakshmi N. Reddi University Graduate School

Florida International University, 2012 


\section{DEDICATION}

This thesis is dedicated to Toni Abbey, Jim Lee, Joe LaRiche, and Derek

Burkholder. Without their love, support, and guidance I would not have been able to make it through this process. Thank you Mom for always being available for proofreading and pep-talks. You have always been my source of inspiration and strength; you set the bar high and I am honored to try to keep up with you. You have guided and supported me in more ways than I can say, thank you for everything you have done. Thank you Dad for always asking why and making me think about the bigger picture. Your humor and low stress attitude are always a welcome relief. Thank you for keeping me grounded. Thank you Joe for making me attempt a balanced life. Your continued support and encouragement kept me going. Your mandatory work breaks kept me fresh, focused, and motivated. Thank you for believing in me and following me in my risky adventures. Thank you Derek for putting up with me at my most stressful time. Your stability, support, and serenity helped anchor me on the stormiest days. You kept me healthy, rested, and, most importantly, fed. Thank you for taking care of me when I was too busy to take care of myself. Finally, I would also like to dedicate this thesis to all of the teachers who have inspired and nurtured me. In particular I would like to thank Paula Clise for showing me early on that learning is fun and being different is a good thing. I would also like to thank Mary Garvin, Keith Tarvin, and Roger Laushman for encouraging and formulating my current research interests and helping me to get the most out of my time at Oberlin. 


\section{ACKNOWLEDGMENTS}

My committee's support and guidance was instrumental in my completion of this thesis. Thank you Drs. Evelyn Gaiser and Mike Heithaus for offering essential and insightful advice that improved the caliber of my project as well as my scientific prowess. My major advisor, Dr. Joel Trexler, also deserves extreme gratitude; your support and advice were essential to my successful completion of this thesis. Thank you for having an open mind and an open door. You said help would always be given at FIU to those in need, and as you know, I was in serious need. Thank you for believing in me, having patience with me, and being willing to meet with me daily. Finally I would like to thank

the entire Trexler lab. Specifically I would like to thank, Mike Bush, Liz Harrison, Ann Hijuelos, J.Matt Hoch, and Joe Parkos for helping me with all of the little things along the way, as well as for being willing to share Joel's precious time with yet another person. Finally, I would like to thank Allison Shideler, without your help all of my models would have failed and I would still be sitting in front of the computer trying to interpret Mplus' screams. Thank you for being supportive and patient with me, and for not minding all of my interruptions. Support for this Master's came from FIU's Presidential Fellowship and the department of Biological Sciences teaching assistantship. 


\title{
ABSTRACT OF THE THESIS \\ RELATIVE ROLE OF DISPERSAL DYNAMICS AND COMPETITION IN NICHE BREADTH
}

\author{
by
}

Robin N. Abbey-Lee

Florida International University, 2012

Miami, Florida

Professor Joel Trexler, Major Professor

Among-individual variation in resource use is pervasive and may have ecosystem-wide effects. This variation between individuals can affect population niche breadth. My study determined if niche breadth was best explained by dispersal of individuals from locations with different prey resources driven by ecosystem level disturbance regimes or competition among individuals inhabiting a site, resulting in dietary partitioning. I used structural equation modeling to examine the direct and indirect effects of several environmental variables spanning gradients of disturbance, competition strength, and food availability on niche breadth of the Eastern Mosquitofish (Gambusia holbrooki). I evaluated two complementary models 1) allowing for only direct effects of disturbance on niche breadth and 2) limiting effects of disturbance on niche breadth to indirect effects via food availability and competitor densities. The partitioning hypothesis excluding direct effects of disturbance on niche breadth was best supported by my data. 


\section{TABLE OF CONTENTS}

CHAPTER

PAGE

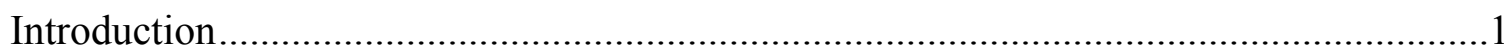

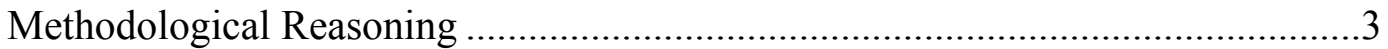

Specific Aims .........................................................................................

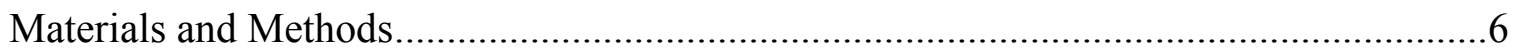

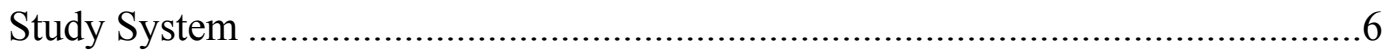

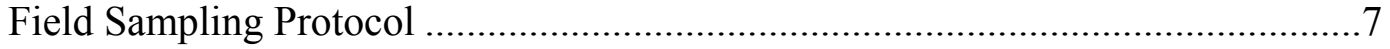

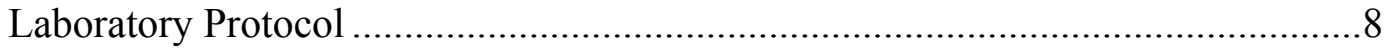

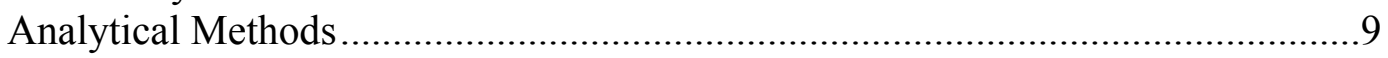

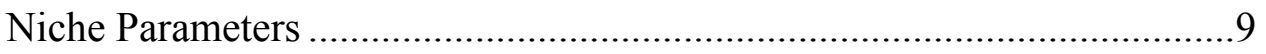

Structural Equation Modeling .................................................................11

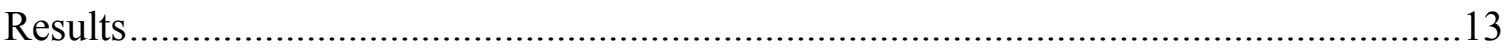

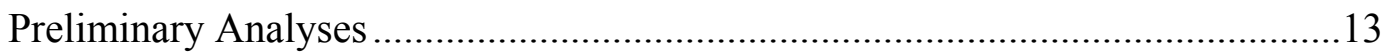

Structural Equation Modeling Results ................................................................14

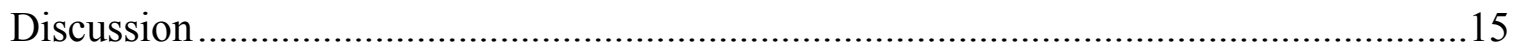

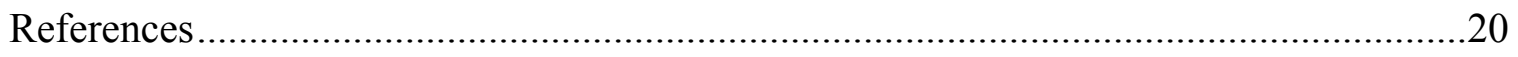




\section{LIST OF TABLES}

TABLE

PAGE

Table 1. Comparison of variance in magnitude of $\delta^{13} \mathrm{C}$ and $\delta^{15} \mathrm{~N}$ range among sites across the Everglades .28

Table 2. Eastern Mosquitofish stomach content analysis from a) Loftus (2000) and b)

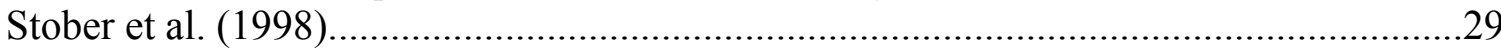

Table 3. Stable isotope metrics for all sampling sites..................................................

Table 4. Bivariate correlations between all isotope metrics .........................................32

Table 5. Factors found in principal components analysis...........................................33

Table 6. Results from principal components factor analysis used to form indicator of niche breadth used in structural equation modeling analyses.........................................34

Table 7. Descriptive statistics for measured parameters included in structural equation

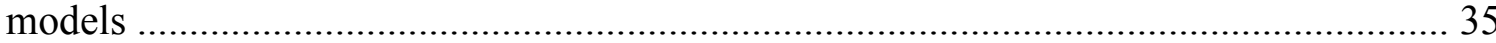

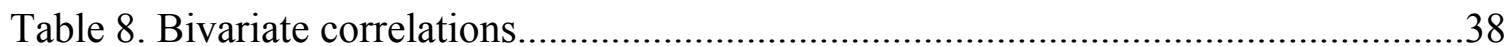




\section{LIST OF ACRONYMS, ABBREVIATIONS, AND SYMBOLS}

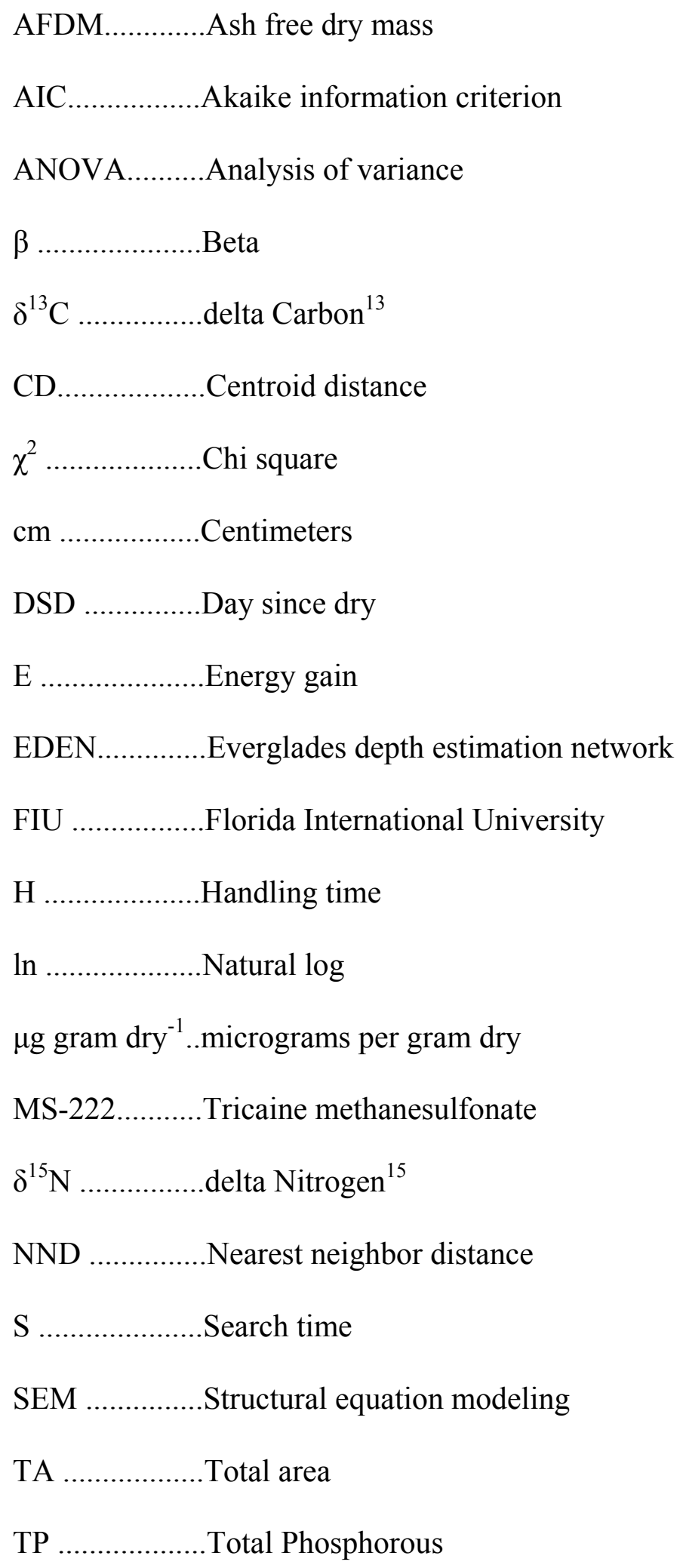




\section{INTRODUCTION}

Among-individual variation in diet has important implications for population stability, the strength of intra-specific competition, and the rate of local adaptation (Bolnick et al. 2011, Bolnick et al. 2003, Violle et al. 2012). Accurate modeling of among-individual variation requires greater understanding of the causes and consequences of this variation. Optimal foraging theory and the niche variation hypothesis can provide a framework for understanding among-individual variation in diet and the resulting changes in niche breadth of populations (e.g., Bolnick et al. 2010, Svanback and Bolnick 2005, Van Valen 1965). All niche-use theories assume that past conditions at a site affect current conditions, and are the basis for predicting future actions of individuals (Beckerman et al. 2002, Ehrlen 2000, Helle et al. 2012, Tanner et al. 1996, Tanner et al. 2011). However, among mobile species inhabiting landscapes with multiple 'sites,' a simple alternative explanation for among-individual variation is that diet resources differed in the environments from which they dispersed (Tilman 1994). Research is needed that examines the effects of past and present local environmental factors and competitive interactions on among-individual variation, as well as changes in niche breadth associated with these factors. My study is a preliminary examination of these factors in shaping the isotopic niche breadth of fish inhabiting a fluctuating environment.

The niche variation hypothesis proposes that populations have constrained niche breadth when exposed to strong inter-specific competition, and have broad niche breadth when released from inter-specific competition and subject only to intraspecific competition (Bolnick et al. 2010, Van Valen 1965). The increased niche breadth in 
species released from inter-specific competition can arise in two general ways: 1) all individuals in a population increase their niche width, or 2) variation among individuals in the population increases. The second mechanism is proposed by the niche variation hypothesis and is often referred to as partitioning, as individuals partition resources among themselves. Early studies often found no support for the niche variation hypothesis (e.g., Soule and Stewart 1970). However, the lack of support is generally a result of these studies using morphology as a proxy for diet variation (Bolnick et al. 2010). Recent studies using more direct measures of diet variation, such as gut content and stable isotope analyses, are generally supportive of the niche variation hypothesis (Arajuo et al. 2008, Bolnick et al. 2010, Bolnick et al. 2007, Codron et al. 2011, Costa et al. 2008, Jack and Wing 2011, Svanback and Bolnick 2007).

Optimal foraging theory provides insight into potential mechanisms for amongindividual variation. According to MacArthur and Pianka (1966), optimal foraging theory states that an activity should be maintained as long as the gains from the activity are greater than the costs, including missed opportunity costs. Other authors have expanded on the original tenets of optimization theory by evaluating how individuals maximize the relationship $\mathrm{E} /(\mathrm{S}+\mathrm{H})$, with $\mathrm{E}$ being energy gain, $\mathrm{S}$ being time searching, and $\mathrm{H}$ being handling time (Stephen and Krebs 1986, Svanback and Bolnick 2005). Local environmental factors (e.g., relative abundance of food sources, quality of food, predation risk) can affect handling time and search time, altering the energy income rate, and causing alternate foraging strategies to be favored with varying local conditions (Schmitz et al. 1998, Staniland et al. 2010, Svanback and Bolnick 2005, Tinker et al. 2009). These studies show that local environmental conditions can affect the foraging strategy and, 
therefore, diet of individuals. Also, if individuals vary in their efficiency of searching for, capturing, or handling prey items, then the energy intake ratio will be different among individuals (Ehlinger 1990). These individual differences allow for variation in diet among individuals exposed to the same local conditions.

Past events can influence the current state of individuals and alter their feeding needs and diets (Beckerman et al. 2002, Ehrlen 2000, Helle et al. 2012, Tanner et al. 1996, Tanner et al. 2011). Also, variation in prey in local environments can affect among-individual variation in consumers (Matthews and Mazumder 2004). Many species move between microhabitats that can vary substantially in the abundance and types of food available (Heithaus et al. 2006, Polis et al. 1997, Sargeant et al. 2007, Tilman 1994). Therefore, for mobile animals, dispersal can potentially affect niche breadth of a population (Thompson et al. 2012). Consequently, models of current population niche breadth need to account for dispersal patterns of individuals and the variation among individuals exposed to different prior conditions, as well as the among-individual variation in diet preference.

\section{Methodological Reasoning}

Stable isotope data are often used to determine isotopic niche breadth. Stable isotope techniques are appropriate for this type of study because they provide information on long-term average diet, as opposed to gut contents that provide snap-shot information. Stable isotope data describe the integrated diet of an individual (Bearhop et al. 2004, Tieszen et al. 1983, Weidel et al. 2011). For the Eastern Mosqutitofish, stable isotope data reflect approximately 50 days, or one-third of an individual's lifespan (Green 2007). 
Thus, stable isotope data are able to answer questions regarding long-term amongindividual variation in diet.

Many studies include prey isotopic data and previous studies have shown that the range of prey species isotopic values is potentially a confounding factor with niche breadth of consumers (Matthews and Mazumder 2004). However, previous work in the Everglades has shown that there is very low variance in the range of prey isotopic values among sites separated at a similar scale to those sampled for this study (Table 1, Williams and Trexler 2006). The specific isotope values vary across the Everglades, but the variation in range covered by the potential prey of Eastern Mosquitofish does not. Thus, in this study prey isotope data were not included.

This study, like many others, was designed using the method of substituting space for time. Over 20 sites were chosen across a hydrologic gradient. By choosing sites that encompass long and short hydroperiod areas, sampling can be done at one time, but patterns can be inferred for the entire season. Sites with short hydroperiods and low water depths are indicative of dry season patterns. Conversely, sites with long hydroperiods and high water depths are indicative of wet season patterns.

Structural equation modeling (SEM) is an important tool for ecological model evaluation because it allows examination of hypotheses that involve a network of interrelated variables (Arhonditsis et al. 2006, Austin 2007, Grace and Pugesek 1998, Sargeant et al. 2011). The SEM technique allows for analysis of both direct and indirect effects, as opposed to traditional regression models that only allow analysis of user defined direct effects. Indirect effects are essential for full understanding of niche breadth dynamics. For example, disturbance variables can directly affect niche breadth, 
but can also indirectly affect niche breadth via effects on food availability and quality. Consequently, SEM is the optimal analytic technique for evaluating the intricacies of these hypotheses.

Specific Aims

I examine two potential mechanisms for determining diet niche breadth of a freshwater fish species, Eastern Mosquitofish (Gambusia holbrooki), in an environment characterized by seasonal disturbance events leading to dispersal.

The first hypothesis, Dispersal, assumes that isotopic niche breadth is affected solely by dispersal patterns driven by disturbance (Figure 1). The Dispersal hypothesis assumes that the observed variation in isotope values of Eastern Mosquitofish results from the past spatial distribution, and subsequent mixing during marsh drying, of individuals and variation in diet options at this regional scale. The Dispersal hypothesis assumes that all Eastern Mosquitofish individuals adopt the same foraging strategy of consuming food in relative proportion to its abundance in the local environment. Therefore variation among individuals in diet is caused by spatially differing local prey availability. Sites with large isotopic niche breadth contain individuals who migrated from different areas that had different prey resources. Sites with such variation could arise from seasonal drying events that concentrate individuals in a few deep refuge areas. The Dispersal hypothesis predicts that areas with long hydroperiods, and therefore high water depth, will have increased isotopic niche breadth because they will have individuals from disparate locations. Also key to this hypothesis is the assumption that there is no relationship between Eastern Mosquitofish isotopic niche breadth and food availability at the collection site, since fish are assumed to have recently moved from 
other areas and therefore have not yet incorporated the local food conditions into their diets.

The second hypothesis, Partitioning, assumes that isotopic niche breadth is determined by intraspecific competition pressure, and that the observed variation in isotope values of Eastern Mosquitofish is a result of partitioning of food resources (Figure 1). The Partitioning hypothesis assumes that individuals adopt an optimal foraging strategy involving partitioning of resources in order to decrease intraspecific competition. Thus, in contrast to the Dispersal hypothesis, the Partitioning hypothesis predicts that fish densities and food sources have direct effects on isotopic diet breadth (Figure 2). The Partitioning hypothesis also allows for indirect effects of hydroperiod and water depth through their effects on food availability and competitor density.

A third model, Full, combines the paths associated with both the Dispersal and Partitioning hypotheses (Figure 1). The Full model evaluates the hypothesis that both mechanisms are working in conjunction, and that direct and indirect effects of disturbance can cause variation among individuals and therefore influence isotopic niche breadth.

\section{MATERIALS AND METHODS}

Study System

Understanding mechanisms of among-individual variation in diet in the Florida Everglades is of particular importance because there is a proposed large-scale project to restore water flow in the Everglades. This project would increase the hydroperiod of many areas of the Everglades and also increase nutrient levels. Therefore, it is essential to understand the role of hydrology and nutrients, as well as interactions between the two, 
in the structuring of communities. The development of better predictive models requires a better understanding of how biotic and abiotic factors interact with among-individual variation.

The Eastern Mosquitofish is an ideal study species for this system because they are meso-consumers and are known for having diverse and variable diets (Blanco et al. 2004, Geddes and Trexler 2003, Loftus 2000, Pyke 2005, Specziar 2004, Table 2). Having a broad potential feeding niche means that there is an opportunity for amongindividual variation in diet. Eastern Mosquitofish are also a practical choice for this study because they are found across the Everglades in relatively high numbers. Therefore it was possible to collect enough individuals for analysis at a number of sites across environmental gradients in the Everglades. Finally, Eastern Mosquitofish are known to disperse and colonize newly flooded areas (Alemadi and Jenkins 2008, Obaza et al. 2011, Trexler et al. 2001), possibly driven by changing food availability (DeAngelis et al. 2010).

\section{Field Sampling Protocol}

Eastern Mosquitofish were sampled following the procedure described in Sargeant et al. (2010) in November and December 2005, during the late wet season, when marshes are near peak water depths. Approximately 50 sites were sampled from a subset of sites generated using a generalized random tessellation stratified survey design (Stevens \& Olsen 2003). All sites were located in wet prairie slough habitats. Of these sites, only 21 yielded enough Eastern Mosquitofish to be included in this study (Figure 3). Fish and large invertebrates were collected by throw-trap sampling as described in Jordan et al. (1997) and Sargeant et al. (2011). Three replicate samples were collected at 
each site. From each throw trap, all small fishes $(<8 \mathrm{~cm})$ and large invertebrates $(>5 \mathrm{~mm})$ were collected. An MS-222 (tricaine methanesulfonate) bath was used to euthanize all collected vertebrates following standard procedures (Nickum et al. 2003). All collected organisms were placed on ice in the field and then frozen at $-17.7^{\circ} \mathrm{C}$ before sample processing. Two periphyton samples were collected. One periphyton sample was processed to determine total phosphorous for use as an indicator of nutrient enrichment (Gaiser et al. 2006). Another periphyton sample was collected for analysis of macroinvertebrate infauna following methods in Liston and Trexler (2005). Both depth and day since dry (DSD) were used as measure of disturbance. Average depth was to the nearest centimeter for each throw trap at the time of sampling and the number of days since the site re-flooded following the most recent drying event (DSD) was calculated using the Everglades Depth Estimation Network's hydrological estimation tool (EDEN, http://sofia.usgs.gov/eden/). The DSD variable is defined as the number of days since the area was first flooded (water level $>5 \mathrm{~cm}$ ) after the most recent drying event, defined as water depth $<5 \mathrm{~cm})$.

\section{Laboratory Protocol}

In the lab, Eastern Mosquitofish samples were processed for isotope analysis following the protocol described in Sargeant et al. (2010). Muscle tissue was removed from the caudal region (on both sides) of each individual and the tissue was then rinsed in deionized water and dried at $55-60^{\circ} \mathrm{C}$ for at least 24 hours. After drying, the tissue was ground into fine powder and analyzed for $\delta^{13} \mathrm{C}$ and $\delta^{15} \mathrm{~N}$ using an isotope ratio mass spectrometer at the FIU Stable Isotope Laboratory. Pee Dee Belemnite was used for $\delta^{13}$ $\mathrm{C}$ standard, and air was used as $\delta^{15} \mathrm{~N}$ standard. Tissues were not subject to lipid 
extraction prior to analysis because previous studies (Williams and Trexler 2006) show little impact of lipid extraction on Everglades consumers. Also, Eastern Mosquitofish have a low $\mathrm{C}: \mathrm{N}$ value, so lipid extraction is generally thought to be unnecessary (Post et al. 2007).

In order to analyze food availability, periphyton cores were processed for macroinvertebrates following the protocol described in Sargeant et al. (2011). Periphyton cores were thawed and all macroinvertebrates were removed, identified, and enumerated using a light microscope. After identification, all individuals were classified into dietary functional groups (herbivores, carnivores, detritivores, and omnivores) on the basis of previous studies (Belicka et al. 2012, Loftus 2000, Thorp and Covich 2001). After the macroinvertebrates were removed, the remaining periphyton was dried at $80{ }^{\circ} \mathrm{C}$ for 48 hours, then incinerated at $500{ }^{\circ} \mathrm{C}$ for 3 hours to determine Ash Free Dry Mass (AFDM) of the sample (Liston 2006). Total infauna density was determined by calculating the number of macroinvertebrates in the sample divided by the AFDM of the sample. The density of each functional group was tallied separately. The relative density of each functional group was determined by dividing the density of the functional group by the total density of infauna.

Analytical Methods

\section{Niche Parameters}

I used the SIAR package in $\mathrm{R}$ to calculate the niche parameters for each site ( $\mathrm{R}$ Development Core Team 2012). Metrics calculated for each site are: $\delta^{13} \mathrm{C}$ and $\delta^{15} \mathrm{~N}$ range, mean nearest neighbor distance (NND), mean distance to centroid (CD) and total area (TA) (Table 3). For all metrics, individuals were plotted in isotope bi-plot space 
using the $\delta^{13} \mathrm{C}$ values for the $\mathrm{x}$-axis and $\delta^{15} \mathrm{~N}$ values for the $\mathrm{y}$-axis. For the range calculations, the lowest $\delta^{13} \mathrm{C}$ and $\delta^{15} \mathrm{~N}$ value at each site is subtracted from the highest value. This measure gives an indication of the spread of the individuals at a site. A larger range indicates more among-individual variation. Nearest neighbor distance was calculated by taking the mean of the Euclidean distances between each individual and its nearest neighbor (the next closest individual in the isotope bi-plot space). The NND is an estimate of packing of individuals in niche space; a short distance indicates closer packing, and therefore more similar and more closely grouped diets among individuals. The centroid is calculated for each site separately, and its coordinates are the average $\delta^{13}$ $\mathrm{C}$ and $\delta^{15} \mathrm{~N}$ for the individuals at the site. Centroid distance was calculated by taking the mean of the Euclidean distances between each individual and the centroid. The CD is also an estimate of the spread of individuals, with short distances meaning less amongindividual variation. Total area was calculated using the convex hull method described in Cornwell et al. (2006). A larger TA means that the individuals cover more space and therefore there is more among-individual variation.

Eastern Mosquitofish were divided into three classes: adult males, adult females, and juveniles. I used ANOVAs on $\delta^{13} \mathrm{C}$ and $\delta^{15} \mathrm{~N}$ to determine if all three classes differed systematically in isotopic values, or could be grouped together for subsequent analysis (SAS Institute 2007). I used factor analysis to develop a single factor score combining all niche metrics because they were highly correlated (Table 4). The factor score was used as a proxy for niche breadth in analyses. I used bivariate Pearson product moment correlations and linear regressions to explore the patterns of relationships among the variables before conducting SEM analyses. Bivariate correlations were run to 
determine basic relationships between each pair of variables without considering shared variance with other variables. Linear regression can be a useful preliminary step prior to conducting SEM analyses because it is a strategy for parsimoniously looking at simultaneous direct effects without concern for the other requirements of SEM (Berk 2010).

\section{Structural Equation Modeling}

I used structural equation modeling (SEM) in Mplus to compare the nested hypotheses (Muthén and Muthén 2005). The SEM technique was selected because it allows researchers to examine hypotheses that involve a network of interrelated predictor and outcome variables (Sargeant et al. 2011). Structural equation modeling provides parameter estimates associated with specific paths that are partial regression coefficients, as well as measures of direct, indirect, and total effects. Another strength of SEM is that it provides fit indices that allow determination of which model (e.g., set of hypotheses) fits the data best (Bentler 1990, Browne and Cudeck 1993, Chou and Bentler 1995). I used the Bollen-Stine (1992) bootstrapping approach for determining probability values because this simulation technique is appropriate for non-normal data. It creates multiple subsamples randomly with replacement from the original sample so that bias in the fit indices and parameter estimates can be evaluated (Bollen and Stine 1992, Ievers-Landis et al. 2011). The bootstrap technique is appropriate for small samples, although the findings should be viewed as exploratory and need to be replicated (Ievers-Landis et al. 2011, Ory and Mokhtarian 2010). 
Prior to conducting the SEM analyses, I calculated Cook's D to determine the influence of each site on the model (Cook 1977, Cook and Weisberg 1982). No sites had overly high influence on the model, so all 21 sites were kept in the final model.

A base model with all paths was developed to describe my trophic hypotheses (Figure 1). Different paths were removed by setting betas to 0 for subsequent models to define alternative hypotheses. For the Dispersal hypothesis, the links between infauna variables and niche and from percent edible periphyton to niche were removed (Figure 3). I tested the hypothesis of dispersal explaining inter-site differences in niche breadth by comparing the AIC of this model to the other models. The path from depth or DSD to niche was removed (Figure 1) and the resulting AIC was compared to the other models to evaluate the Partitioning hypothesis. The Dispersal hypothesis was derived from the assumption that variation among individuals will increase with increasing water depth and DSD. Areas with increased depth and DSD are refuge areas; therefore they are the most likely to contain individuals that have been mixed together from disparate sites. Previous work on Eastern Mosquitofish genetics has supported this hypothesis (McElroy et al. 2011). Under this hypothesis, no effect of infauna densities or percent edible periphyton on niche is expected because these factors were measured at the capture site. The Dispersal hypothesis assumes that the Eastern Mosquitofish were not feeding at the capture site until recently, and therefore food availability at the capture site should have little correlation with Eastern Mosquitofish isotope signatures. In contrast, the Partitioning hypothesis is derived from the assumption that among-individual variation arises from individual differences in foraging strategies, preferences, or success. Each individual is hypothesized to use a subset of the available resources. With these 
assumptions, density of competitors and food availability should influence niche variation. Therefore, it is expected that the paths from infauna density and percent edible periphyton to niche should be different from zero (Figure 1). Also, indirect paths influenced by both heterospecific and conspecific competitors should increase amongindividual variation in niche. Model fit was determined using a Chi Square Test of Model Fit, only models with $p>0.05$ were considered (Bentler 1990, Browne and Cudeck 1993, Chou and Bentler1995). Akaike information criterion (AIC) was compared between models to determine the best model(s).

\section{RESULTS}

\section{Preliminary Analyses}

The $\delta^{13} \mathrm{C}$ and $\delta^{15} \mathrm{~N}$ values of individuals did not differ by sex/age group $\left(\delta^{13} \mathrm{C}\right.$ : $\mathrm{F}_{2,609}=2.81 \mathrm{p}=0.06 ; \delta^{15} \mathrm{~N}: \mathrm{F}_{2,609}=1.03 \mathrm{p}=0.36$ ). Thus, for each site, all juvenile, adult male, and adult female individuals were grouped together for isotope metric calculations.

I examined the frequency distributions and univariate statistics for each variable to determine if they met the assumptions of normality. All of the variables except depth were skewed and were therefore $\ln +1$ transformed (Tabachnick and Fidell 2007). After transformation, only DSD remained skewed and therefore the SEM was run using depth as the disturbance variable.

Many of the isotope metrics were strongly correlated (Table 4) so they were condensed into a single variable using varimax rotation in principal components analysis (Table 5). Only one factor had an eigenvalue greater than 1.00, so only one factor was formed using factor scores (Table 6). My study encompassed sites spanning a range of 
disturbance (water depth), nutrient (periphyton TP), food availability (infauna density and edible periphyton) and competition (fish density) gradients (Table 7).

Two factors were correlated with niche breadth: heterospecific fish density, and conspecific density (Table 8 ). The Full model was tested using a linear regression model of niche predicted by the variables hypothesized to have direct effects in the SEM model: depth, percent edible periphyton, and relative density of all infauna groups $\left(\mathrm{F}_{6,14}=3.2, \mathrm{p}\right.$ $\left.=0.03, \mathrm{R}^{2}=0.58\right)$. Of the independent variables considered, the percent edible periphyton contributed the most support to this model. Niche breadth increased with increasing percent edible periphyton. Linear regressions of the Partitioning (no depth variable) and Dispersal (only depth variable) models were not significant $(\mathrm{p}>0.08)$.

\section{Structural Equation Modeling Results}

For all models using depth as an indicator of disturbance (Dispersal, Partitioning, Full), the Bollen-Stine $\chi^{2}$ test indicated no lack-of-fit ( $\left.\mathrm{p} \geq 0.20\right)$. The Full model provided the lowest AIC (709.4), followed by the Partitioning model (713.2) and then the Dispersal model (715.2). All variables with direct links to niche breadth, except for omnivore density, had approximately equal effect sizes ( $\beta=0.40$ to 0.61 ). Detritivore density and herbivore density negatively affected niche breadth, whereas carnivore density, percent edible periphyton, and depth positively affected niche breadth (Figure 4). The indirect effects of heterospecific fish density and depth on niche breadth were the greatest of the indirect effects ( $\beta=0.21,-0.22$ respectively). The model was able to predict 67 percent of the variance in niche breadth $\left(\mathrm{R}^{2}=0.67\right)$ and 49 percent of the variance in percent edible periphyton $\left(\mathrm{R}^{2}=0.49\right)$. The model was able to predict less than 36 percent of the variance for all of the other parameters. 
An identical SEM was run using DSD instead of depth and a similar pattern was observed. For all models the Bollen-Stine $\chi^{2}$ test indicated no lack-of-fit. The Full model had lowest AIC (615.5), then Partitioning (616.5), then the Dispersal model (618.5).

\section{DISCUSSION}

The present study evaluated two hypothetical explanations for variation in isotopic niche breadth of Eastern Mosquitofish in an environment with seasonal fluctuations in hydrology. I examined two possible determinants of isotopic niche breadth by comparing overall model fit of 1) a model using disturbance and dispersal dynamic as independent variables and 2) a model using competition and partitioning of resources as independent variables. In the present exploratory study of isotopic niche breadth, the Partitioning model that excluded a direct link between water depth at the site fit better than the Dispersal model that included the direct link between these two variables. Thus, these findings do not support the Dispersal hypothesis, which required a direct link between depth and niche. However, the Full model, with both direct and indirect paths had the lowest AIC value and described the most variance in niche breadth. In a complementary model that uses days since dry as a measure of disturbance at the site instead of depth, the same pattern of results was found. Although depth and DSD are often correlated and used as measures of disturbance, they are not synonymous. In the current study, depth was correlated with DSD $(r=0.38)$ but there were much stronger correlations between other variables. The DSD variable is a measure of time since disturbance, but depth is more nuanced. Water depth can have multiple effects on a site. Increased depth is indicative of increased hydroperiod length, but also of a potential increase in predation pressure, competition, and food availability. Therefore, since the 
models with DSD did not explain as much of the observed variance in isotopic niche breadth as the models with depth, the role of disturbance in shaping isotopic niche breadth is further decreased.

In the SEM model that represented the Full hypothesis, the largest direct effect on niche variability was detritivore density, although percent edible periphyton, depth, carnivore density, and herbivore density had similarly strong effects as well. Detritivore density and herbivore density were negatively related to isotopic niche breadth, such that increases in their density caused a decrease in Eastern Mosquitofish isotopic niche breadth. In contrast, carnivore density, percent edible periphyton, and depth had positive relationships with isotopic niche breadth, indicating that increases in these variables lead to increased Eastern Mosquitofish isotopic niche breadth. Heterospecific fish density and depth had the largest indirect effects on niche variability, through their effects on prey availability. Heterospecific fish density was positively related to isotopic niche breadth. The direct effects of depth on isotopic niche breadth were positive, however the indirect effects were negative.

The bivariate correlations indicated that isotopic niche breadth was positively correlated with both heterospecific and conspecific fish densities. These correlations support the conclusions of the SEM and partially support the Partitioning hypothesis. The Partitioning hypothesis assumes that Eastern Mosquitofish individuals use different foraging tactics and feed on a subset of the available food sources. Niche partitioning is often attributed to both intra- and inter-specific competition (Chesson 2000, Emmons 1980, Langeland et al. 1991, Wiens 1977). Optimal foraging theory suggests that increased competitors can induce niche partitioning to decrease competitive effects 
among individuals (Svanback and Bolnick 2005). However, the niche variation hypothesis predicts that increased inter-specific competition will decrease niche breadth, and this study found a positive relationship of heterospecific fish on isotopic nice breadth. The similar response to both inter- and intra-specific competition may be a result of similarities among fish species in the Everglades. The SEM did not allow direct effects of fish densities on isotopic niche breadth because their effects are thought to be mediated through their effects on food availability (Marks et al. 2000, Wootton and Power 1993). Therefore, only the indirect effects of fish density on isotopic niche breadth were examined in the SEM. The indirect effect of Eastern Mosquitofish density on niche was slightly smaller than that of heterospecific fish, but both effect sizes were about half the strength of the direct effects, indicating that the level of both conspecific and heterospecific competition may influence Eastern Mosquitofish feeding strategies and increase niche partitioning in this study. Also, the indirect effects of fish densities were approximately equal to the indirect effects of depth, supporting the Full model and indicating that food availability and hydrology are equally important in predicting isotopic niche breadth in this study.

The Partitioning hypothesis also predicts that the indirect effects of hydroperiod on isotopic niche breadth via increased fish density and food sources are more important than the direct effects. The SEM and bivariate correlation results do not support this assumption. The food availability variables were not strongly correlated with depth or DSD, indicating little possibility for indirect effects of disturbance on isotopic niche breadth. The SEM also showed a very small negative indirect effect of disturbance on isotopic niche breadth and a strong positive direct effect. The difference in sign of these 
effects is likely a result of depth's myriad effects on the environment. Depth directly increases isotopic niche breadth as supported by the sign of the bivariate correlations and linear regressions. However, when the interactions of depth with fish densities and infauna densities are considered, the sign changes. Future research is needed to tease apart the contrasting effects of depth on the system. A linear regression model of isotopic niche breadth defined by the full suite of parameters (depth, percent edible periphyton, and infauna group relative densities) explained 13\% more of the variance in isotopic niche breadth as compared to a model with all the parameters but depth. However, depth had the smallest effect size of the parameters in the model. Even though the indirect effects of depth were small, the effects of depth on isotopic niche breadth via food availability was approximately an order of magnitude greater than the effects of depth on isotopic niche breadth via fish densities via food availability. The results suggest that depth likely influences isotopic niche breadth in this study by affecting food availability, not fish densities. The results support previous work showing that hydroperiod length and/or water depth is positively correlated with increased infauna densities (Leeper and Taylor 1998, Liston 2006, Murkin and Kadlec 1986) and edible periphyton (Gottlieb et al. 2006). Detritivore and carnivore density and percent edible periphyton were, in turn, correlated with hetero- and conspecific fish densities. Therefore, depth likely influences isotopic niche breadth by affecting food availability, which alters the strength of competition and, therefore, isotopic niche breadth.

The present study had some limitations that influence the generalizability of the findings. Data were collected in the wet season, meaning that many areas of the marsh were near peak water depths for the year. I chose to sample during the wet season to 
have sites that spanned a larger gradient in hydroperiod and water depth. I used the space for time substitution method so that a snapshot study could provide season level predictions. However, the high water conditions may have affected my ability to detect the effects of dispersal dynamics on niche partitioning. Evidence for dispersal effects should be stronger in the dry season when fish are condensed in few refuge areas (Kushlan 1974, Lake 2003, McElroy et al. 2011, Parkos et al. 2011, Perry and Bond 2009, Ruetz et al. 2005). Or just after marsh re-flooding when individuals from the refuges are still moving through the marsh in a mixed dispersal front. Therefore, the current study may have missed evidence for the Dispersal hypothesis because of the increased connectivity during the wet season. Further work examining these relationships in the dry season is needed to determine if the same drivers of amongindividual variation in diet are important throughout the year. Furthermore, replication of these findings in other ecosystems with other species would increase confidence that these findings are not unique to the Everglades or Eastern Mosquitofish. 


\section{REFERENCES}

Alemadi, S.D. and D.G. Jenkins. 2008. Behavioral constraints for the spread of the Eastern Mosquitofish, Gambusia holbrooki (Poeciliidae). Biological Invasions 10:59-66.

Araujo, M.S., P.R. Guimaraes, R. Svanback, A. Pinheiro, P. Guimaraes, S.F. dos Reis and D.I. Bolnick. 2008. Network analysis reveals contrasting effects of intraspecific competition on individual vs. population diets. Ecology 89: 1981-1993.

Arhonditsis, G.B., C.A. Stowb, L.J. Steinberg, M.A. Kenney ,R.C. Lathrop, S.J. McBride and K.H. Reckhowa. 2006. Exploring ecological patterns with structural equation modeling and Bayesian analysis. Ecological Modelling 192: 385-409.

Austin, M. 2007. Species distribution models and ecological theory: a criticl assessment and some possible new approaches. Ecological Modelling 200: 1-19.

Bearhop, S., C.E. Adams, S.Waldron, R.A. Fuller and H. Macleod. 2004. Determining trophic niche width: a novel approach using stable isotope analysis. Journal of Animal Ecology 73: 1007-1012.

Beckerman, A., T.G. Benton, E. Ranta, V. Kaitala, and P. Lundberg. 2002. Population dynamic consequences of delayed life-history effects. Trends in Ecology and Evolution 17: 263-269.

Belicka, L.L, E.R. Sokol, J.M. Hoch, R. Jaffé and J.C. Trexler. 2012. A Molecular and Stable Isotopic Approach to Investigate Algal and Detrital Energy Pathways in a Freshwater Marsh. Wetlands 32:531-542.

Bentler, P.M. 1990. Comparative fit indices in structural models. Psychological Bulletin 107: 238-246.

Berk, R. 2010. What You Can and Can't Properly Do with Regression. Journal of Quantitative Criminology 26:481-487.

Blanco, S., S.Romo, and M.-J. Villena. 2004. Experimental study on the diet of mosquitofish (Gambusia holbrooki) under different ecological conditions in a shallow lake. International Review of Hydrobiology 89:250-262.

Bollen, K.A. and R.A. Stine.1992. Bootstrapping goodness-of-fit measures in structural equation models. Sociological Methods \& Research 21: 205-229.

Bolnick D.I., P. Amarasekare, M.S. Araujo, R. Burger, J.M. Levine, M. Novak, V.H.W. Rudolf, S.J. Schreiber, M.C. Urban, and D.A. Vasseur. 2011. Why intraspecific variation matters in community ecology. Trends in Ecology and Evolution 26:183-192. 
Bolnick, D.I., T. Ingram, W.E. Stutz, L.K. Snowberg, O.L. Lau and J.S. Paull. 2010. Ecological release from interspecific competition leads to decoupled changes in population and individual niche width. Proceedings of the Royal Society B Biological Sciences 277: 1789-1797.

Bolnick, D.I., R. Svanback, M.S. Araujo and L. Persson. 2007. Comparative support for the niche variation hypothesis that more generalized populations also are more heterogeneous. Proceedings of the National Academy of Sciences 104: 10075-10079.

Bolnick, D.I., R.Svanback, J.A. Fordyce, L.H. Yang, J.M. Davis, C.D. Hulsey, and M.L Forister. 2003. The ecology of individuals: incidence and implications of individual specialization. The American Naturalist 161: 1-28.

Browne, M.W. and R. Cudeck. 1993. Alternative ways of assessing model fit. In K.A. Bollen and J.S. Long (Eds.), Testing structural equation models (pp. 136-162). Newbury Park, CA: Sage.

Chesson, P. 2000. Mechanisms of maintenance of species diversity. Annual Review of Ecology and Systematics 31: 343-366.

Chou, C.P. and P.M. Bentler. 1995. Estimates and tests in structural equation modeling. In R.H. Hoyle (Ed.), Structural Equation Modeling: Concepts, Issues, and Applications (pp. 37-55). Thousand Oaks, CA: Sage.

Codron, D., J. Hull, J.S. Brink, J. Codron, D. Ward, and M. Clauss. 2011. Effect of competition on niche dynamics of syntopic grazing ungulates: contrasting the predictions of habitat selection models using stable isotope analysis. Evolutionary Ecology Research 217-235.

Cook, R.D. 1977. Detection of Influential Observation in Linear Regression. Technometrics 19: 15-18.

Cook, R.D. and S. Weisberg. 1982. Residuals and influence in regression. New York: Chapman and Hall.

Cornwell, W.K., D.W. Schwilk, and D.D. Ackerly. 2006. A trait-based test for habitat filtering: Convex hull volume. Ecology 87:1465-1471.

Costa, G.C., D.O. Mesquita, G.R. Colli and L.J. Vitt. 2008. Niche expansion and the niche variation hypothesis: does the degree of individual variation increase in depauperate assemblages? The American Naturalist 172: 868-877.

DeAngelis, D. L., J. C. Trexler, C. Cosner, A. Obaza, and F. Jopp. 2010. Fish population dynamics in a seasonally varying wetland. Ecological Modelling 221:1131-11. 
EDEN, http://sofia.usgs.gov/eden/

Ehlinger, T.J. 1990. Habitat choice and phenotype-limited feeding efficiency in bluegill: individual differences and trophic polymorphism. Ecology 886-896.

Ehrlen, J. 2000. The dynamics of plant populations: does the history of individuals matter? Ecology 81:1675-1684.

Emmons, L.H. 1980. Ecology and resource partitioning among nine species of African rain-forest squirrels. Ecological Monographs 50: 31-54.

Gaiser E. E., D.L. Childers, R.D. Jones, J.H. Richards, L.J. Scinto, and J.C. Trexler. 2006. Periphyton responses to eutrophication in the Florida Everglades: cross- system patterns of structural and compositional change. Limnology and Oceanography 51: 617630.

Geddes, P. and J.C. Trexler. 2003. Uncoupling of omnivore-mediated positive and negative effects on periphyton mats. Oecologia 136:585-595

Gottlieb, A.D., J.H. Richards, and E.E. Gaiser. 2006. Comparative study of periphyton community structure in long and short-hydroperiod Everglades marshes. Hydrobiologia 569:195-207.

Grace, J.B and B.H. Pugesek. 1998. On the use of path analysis and related procedures for the investigation of ecological problems. The American Naturalist 152: 151-159.

Green, D.P. 2007. Community structure and physiological stresses of oligohaline zone fishes in South Florida. Unpublished Master's Thesis Florida International University, United States, Florida.

Heithaus, M.R., I.M Hamilton, A.J. Wirsing, and L.M. Dill. 2006. Validation of a randomization procedure to assess animal habitat preferences: microhabitat use of tiger sharks in a seagrass ecosystem. Journal of Animal Ecology 75: 666-676.

Helle, H., E. Koskela, and T. Mappes. 2012. Life in varying environments: experimental evidence for delayed effects of juvenile environment on adult life history. Journal of Animal Ecology 81: 573-582.

Ievers-Landis, C.E, C.J. Burant, and R. Hazen. 2011. The concept of bootstrapping of structural equation models with smaller samples: an illustration using mealtime rituals in diabetes management. Journal of Developmental \& Behavioral Pediatrics 32:619 -626. 
Jack, L. and S.R. Wing. 2011. Individual variability in trophic position and diet of a marine omnivore is linked to kelp bed habitat. Marine Ecology Progress Series 443: 129139.

Jordan, D.F., S. Coyne, and J.C. Trexler. 1997. Sampling fishes in vegetated habitats: effects of habitat structure on sampling characteristics of the $1-\mathrm{m}^{2}$ throw trap. Transaction of the American Fisheries Society 126: 1012-1020.

Kushlan, J. A. 1974. Effects of a natural fish kill on the water quality, plankton, and fish population of a pond in the Big Cypress Swamp, Florida. Transactions of the American Fisheries Society 103: 235-243.

Lake, P. S. 2003. Ecological effects of perturbation by drought in flowing waters. Freshwater Biology 48: 1161-1172.

Langeland, A., J.H. Abee-Lund, B. Jonsson, and N. Jonsson. 1991. Resource partitioning and niche shift in artic charr Salvelinus alpinus and brown trout Salmo trutta. Journal of Animal Ecology 60: 895-912.

Leeper, D. A. and B. E. Taylor, 1998. Abundance, biomass and production of aquatic invertebrates in Rainbow Bay, a temporary wetland in South Carolina, USA. Archiv Fur Hydrobiologie 143: 335-362.

Liston, S. E. 2006. Interactions between nutrient availability and hydroperiod shape macroinvertebrate communities in Florida Everglades marshes. Hydrobiologia 569:343357

Liston, S.E. and J.C. Trexler. 2005. Spatiotemporal patterns in community structure of macroinvertebrates inhabiting calcareous periphyton mats. Journal of the North American Benthological Society 24:832-844.

Loftus, W.F. 2000. Accumulation and fate of Mercury in an Everglades aquatic food web. Ph.D. dissertation, Florida International University, United States, Florida. Publication No. AAT 9991050.

MacArthur, R.H. and E.R. Pianka. 1966. On optimal use of a patchy environment. The American Naturalist 100: 603-609.

Marks J. C., M. E Power. and M.S. Parker. 2000. Flood disturbance, algal productivity, and interannual vari- ation in food chain length. Oikos, 90, 20-27.

Matthews, B. and A. Mazumder 2004. A critical evaluation of intrapopulation variation of $\delta 13 \mathrm{C}$ and isotopic evidence of individual specialization. Oecologia 140: 361-371. 
McElroy, T.C., K.L. Kandl and J.C. Trexler. 2011. Temporal population genetic structure of Eastern Mosquitofish in a dynamic aquatic landscape. Journal of Heredity 102: 678687.

Murkin, H. R. and J. A. Kadlec, 1986. Responses by benthic macroinvertebrates to prolonged flooding or marsh habitat. Canadian Journal of Zoology 64: 65-72.

Muthén, L.K. and B.O. Muthén 2005. Mplus User’s Guide. 3rd edition. Muthén \& Muthén, Los Angeles.

Nickum, J.G., H. L. Bart, P.R. Bowser, I. E. Greer, C. Hubbs, J. A. Jenkins, J. R. MacMillan, J. W. Rachlin , J. D. Rose, P. W. Sorensen, and J. R. Tomasso. 2003. Guidelines for the use of fishes in research. The American Fisheries Society.

Obaza, A., D. L. DeAngelis, and J. C. Trexler. 2011. Using data from an encounter sampler to model fish dispersal. Journal of Fish Biology 78: 495-513.

Ory, D.T. and P.L. Mokhtarian. 2010. The impact of non-normality, sample size and estimation technique on goodness-of-fit measures in structural equation modeling: evidence from ten empirical models of travel behavior. Quality \& Quantity 44:427-445

Parkos, J.J., C.R. Ruetz, and J.C. Trexler. 2011. Distrubance regime and limits on benefits of refuge use for fishes in a fluctuating hydroscape. Oikos 120: 1519-1530.

Perry, G. L. W. and Bond, N. R. 2009. Spatially explicit modeling of habitat dynamics and fish population persistence in an intermittent lowland stream. Ecological Applications 19: 731-746.

Polis, G.A., R.D. Holt, B.A. Menge and K.O. Winemiller. 1996. Time, space, and life history: influences on food webs. p 435-460 in G.A. Polis and K.O. Winemiller (eds.) Food webs: integration of patterns and dynamics. Chapman and Hall, London.

Post, D. M., C.A. Layman, D.A. Arrington, G. Takimoto, J. Quattrochi, and C.G. Montana. 2007. Getting to the fat of the matter: Models, methods and assumptions for dealing with lipids in stable isotope analyses. Oecologia 152:179-189.

Pyke, G.H. 2005. A review of the biology of Gambusia affinis and G. holbrooki. Reviews in Fish Biology and Fisheries 15: 339-365.

R Development Core Team. 2012. R: A language and environment for statistical computing. R Foundation for Statistical Computing, Vienna, Austria. ISBN 3-900051-070, URL http://www.R-project.org/. 
Ruetz, C. R., J.C. Trexler, F. Jordan, W.F. Loftus, and S.A. Perry. 2005. Population dynamics of wetland fishes: spatio-temporal patterns synchronized by hydrological disturbance? Journal of Animal Ecology 74: 322-332.

Sargaent, B.L., A.J. Wirsing, M.R. Heithaus, and J. Mann. 2007. Can environmental heterogeneity explain individual foraging variation in wild bottlenose dolphins (Tursiops sp.)? Behavioral Ecology and Sociobiology 61:679-688.

Sargeant, B.L., E.E. Gaiser, and J.C. Trexler. 2010. Indirect and direct controls of macroinvertebrates and small fish by abiotic factors and trophic interactions in the Florida Everglades. Freshwater Biology 56: 2334-2346.

Sargeant, B.L, E.E. Gaiser, and J.C. Trexler. 2011. Indirect and direct controls of macroinvertebrates and small fish by abiotic factors and trophic interactions in the Florida Everglades. Freshwater Biology 56:2334-2346.

SAS Institute. 2007. SAS v.9.2. Cary, USA

Schmitz, O.J., J.L. Cohon, K.D. Rothley, and A.P. Beckerman. 1998. Reconciling variability and optimal behaviour using multiple criteria in optimization models. Evolutionary Ecology 12:73-94.

Soule, M. and B.R. Stewart. 1970 The 'niche variation' hypothesis: a test and alternatives. American Naturalist 104, 85-97.

Specziar, A. 2004. Life history pattern and feeding ecology of the introduced eastern mosquitofish, Gambusia holbrooki, in a thermal spa under temperate climate, of Lake Heviz, Hungary. Hydrobiologia 522: 249-260.

Staniland, I.J., N.Gales, N.L. Warren, S.L. Robinson, S.D. Goldsworthy, and R.M. Casper. 2010. Geographical variation in the behaviour of a central place forager: Antarctic fur seals foraging in contrasting environments. Marine Biology 157:2383-2396.

Stephens, D. W. and Krebs, J. R. 1986. Foraging Theory. Princeton University Press, Princeton, New Jersey.

Stevens D. L. and A.R. Olsen. 2003. Variance estimation for spatially balanced samples of environmental resources. Environmetrics 14: 593-610.

Stober, Q.J., D. Scheidt, R. Jones, K. Thornton,L. Gandy, D. Stevens, J.C. Trexler, and S. Rathbun. 1998. South Florida Ecosystem Assessment: Final Technical Report, Phase I. Monitoring for Adaptive Management. EPA 904-R-98-002, Appendix D. 
Svanback, R. and D.I. Bolnick. 2005. Intraspecific competition affects the strength of individual specialization: an optimal diet theory method. Evolutionary Ecology Research 7: 993-1012.

Svanback, R. and D.I. Bolnick. 2007. Intraspecific competition drives increased resource use diversity within a natural population. Proceedings of the Royal Society B Biological Sciences 274: 839-844.

Tabachnick, B. G. and L.S. Fidell. 2007. Using multivariate statistics (5th ed.). Boston: Allyn and Bacon.

Tanner, C.J., G.D. Salali, and A.L. Jackson. 2011. The ghost of social environments past: dominance relationships include current interactions and experience carried over from previous groups. Biology Letters 7:818-821.

Tanner, J.E., T.P. Hughes, and J.H. Connell. 1996. The Role of History in Community Dynamics: A Modelling Approach. Ecology 77:108-117.

Thompson, J.A., M.R. Heithaus, D.A. Burkholder, J.J. Vaudo, A.J. Wirsing, and L.M. Dill. 2012. Site specialists, diet generalists? Isotopic variation, site fidelity, and foraging by loggerhead turtles in Shark Bay, Western Australia. Marine Ecology Progress Series 213-226.

Thorp, J.H, and A.P. Covich 2001. Ecology and Classification of North American Freshwater Invertebrates, Second Edition. Waltham, MA: Academic Press.

Tieszen, L.L, T.W. Boutton, K.G. Tesdahl and N.A. Slade. 1983. Fractionation and turnover of stable carbon isotopes in animal tissues: implications for $\delta^{13} \mathrm{C}$ analysis of diet. Oecologia 57:32-37.

Tilman, D. 1994. Competition and biodiversity in spatially structured habitats. Ecology 75:2-16.

Tinker, M.T. M. Mangel, and J.A. Estes. 2009. Learning to be different: acquired skills, social learning, frequency dependence, and environmental variation can cause behaviorally mediated foraging specializations. Evolutionary Ecology Research 11:841869.

Trexler, J. C., W. F. Loftus, C. F. Jordan, J. Chick, K. L. Kandl, T. C. McElroy, and O. L. Bass. 2001. Ecological scale and its implications for freshwater fishes in the Florida Everglades. Pp. 153 - 181, in J. W. Porter and K. G. Porter (eds.) The Everglades, Florida Bay, and Coral Reefs of the Florida Keys: An Ecosystem Sourcebook. CRC, Boca Raton. 
Van Valen, L. 1965. Morphological variation and width of ecological niche. The American Naturalist 99: 377-390.

Violle, C., B.J. Enquist, B.J. McGill, L. Jiang, C.H. Albert, C. Hulshof, V. Jung, and J. Messier. 2012. The return of the variance: intraspecific variability in community ecology. Trends in Ecology and Evolution 27:244-252.

Weidel, B.C., S.R. Carpenter, J.F. Kitchell, and J. Vander Zanden. 2011. Rates and components of carbon turnover in fish muscle: insights from bioenergetics models and a whole-lake ${ }^{13} \mathrm{C}$ addition. Canadian Journal of Fisheries and Aquatic Sciences 68: 387399.

Wiens, J.A. 1977. Competition and variable environments. American Scientist 65:590597.

Williams A. J. and J.C. Trexler. 2006. A preliminary analysis of the correlation of foodweb characteristics with hydrology and nutrient gradients in the southern Everglades. Hydrobiologia, 569: 493-504.

Wotton, J.T. and M.E. Power. 1993. Productivity, consumers, and the structure of a river food chain. Proceedings of the National Academy of Sciences 90:1384-1387. 
Table 1. Comparison of variance in magnitude of $\delta^{13} \mathrm{C}$ and $\delta^{15} \mathrm{~N}$ range among sites across the Everglades collected by Williams and Trexler (2006).

\begin{tabular}{lccccc}
\hline & $\begin{array}{c}\text { Average } \\
\text { Range }\end{array}$ & Variance & Std.Dev & Std. Error & CV \\
\hline Wet Season & & & & & \\
$\delta^{15} \mathrm{~N}$ & 2.34 & 0.35 & 0.60 & 0.18 & 0.15 \\
$\delta^{13} \mathrm{C}$ & -2.42 & 0.79 & 0.89 & 0.27 & 0.32 \\
Dry Season & & & & & \\
$\delta^{15} \mathrm{~N}$ & 1.90 & 0.93 & 0.96 & 0.27 & 0.49 \\
$\delta^{13} \mathrm{C}$ & -2.54 & 1.55 & 1.24 & 0.34 & 0.61 \\
\hline
\end{tabular}


Table 2. Eastern Mosquitofish stomach content analysis from a) Loftus (2000) and b) Stober et al. (1998). A) reports the number of each food item found in all stomachs, the number of fish the food item appeared in (frequency), the total volume of each prey category (mililiters), and the percentages of the totals for these three measures for each food item category. Trace indicates volumes less than 0.0003 mililiters. B) reports the number of each food item found in all stomachs, the weight of each prey category, and the percentages of the totals for these two measures for each food item category.

\begin{tabular}{|c|c|c|c|c|c|c|}
\hline Food Item & Number & $\begin{array}{c}\% \\
\text { Number }\end{array}$ & Frequency & $\begin{array}{c}\% \\
\text { Frequency }\end{array}$ & Volume & $\begin{array}{c}\% \% \\
\text { Volume }\end{array}$ \\
\hline \multicolumn{7}{|l|}{ Vegetation } \\
\hline Periphyton & - & - & 25 & 48.08 & 0.006 & 7.60 \\
\hline \multicolumn{7}{|l|}{ Invertebrates } \\
\hline Rotatoria & 148 & 23.13 & 17 & 32.69 & Trace & \\
\hline Nematoda & 2 & 0.31 & 2 & 3.85 & Trace & \\
\hline Bryozoa & 3 & 0.47 & 3 & 5.77 & Trace & \\
\hline \multicolumn{7}{|l|}{ Crustacea } \\
\hline Cladocera & 133 & 20.78 & 37 & 71.15 & 0.004 & 5.07 \\
\hline Copepoda & 32 & 5.00 & 15 & 28.85 & 0.0005 & 0.63 \\
\hline Ostracoda & 1 & 0.16 & 1 & 1.92 & Trace & \\
\hline Hyalella azteca & 12 & 1.88 & 11 & 21.15 & 0.004 & 5.07 \\
\hline \multicolumn{7}{|l|}{ Arachnoidea } \\
\hline Araneae & 5 & 0.78 & 5 & 9.61 & 0.004 & 5.07 \\
\hline Spider & 4 & 0.63 & 4 & 7.69 & 0.003 & 3.80 \\
\hline \multicolumn{7}{|l|}{ Insecta } \\
\hline Collembola & 90 & 14.06 & 34 & 65.38 & 0.007 & 8.87 \\
\hline Coleoptera & 1 & 0.16 & 1 & 1.92 & 0.0005 & 0.63 \\
\hline Tipulidae & 3 & 0.47 & 3 & 5.77 & 0.0005 & 0.63 \\
\hline Zygoptera & 1 & 0.16 & 21 & 40.38 & 0.004 & 5.07 \\
\hline Hemiptera & 5 & 0.78 & 4 & 7.69 & 0.001 & 1.27 \\
\hline Notonectidae & 4 & 0.63 & 2 & 3.85 & 0.001 & 1.27 \\
\hline Coleoptera larvae & 1 & 0.16 & 1 & 1.92 & 0.0005 & 0.63 \\
\hline Chronomid pupae/adult & 106 & 16.56 & 41 & 78.85 & 0.03 & 38.02 \\
\hline Chironomidae & 68 & 10.63 & 17 & 32.69 & 0.007 & 8.62 \\
\hline Tanypodinae & 5 & 0.78 & 4 & 7.69 & 0.0006 & 0.76 \\
\hline Orthocladiinae & 3 & 0.47 & 2 & 3.85 & 0.0003 & 0.38 \\
\hline
\end{tabular}


Ceratopogonidae

Unid. insects

Pisces

Fish scales*

Larval fish

Miscellaneous

Unid. animals

Unid. animal material

$\mathrm{n}=52$

B)

\begin{tabular}{ccccc}
\hline & Count & \% Count & Weight & \% Weight \\
\hline Cladoceran & 499 & 0.18 & 0.01 & 0.02 \\
Mite & 177 & 0.06 & 0.01 & 0.03 \\
Dipteran & 1123 & 0.39 & 0.10 & 0.34 \\
Chironomid & 238 & 0.08 & 0.03 & 0.09 \\
Periphyton & 621 & 0.22 & 0.11 & 0.35 \\
Other & 192 & 0.07 & 0.05 & 0.17 \\
\hline
\end{tabular}

$\mathrm{n}=1270$

$\begin{array}{llllll}4 & 0.63 & 4 & 7.69 & 0.001 & 1.52 \\ 6 & 0.94 & 3 & 5.77 & 0.001 & 1.27\end{array}$

\begin{tabular}{cccccc}
160 & - & 12 & 23.08 & 0.001 & 1.27 \\
1 & 0.16 & 1 & 1.92 & 0.001 & 1.27 \\
& & & & & \\
2 & 0.31 & 2 & 3.85 & 0.001 & 1.27 \\
- & - & 2 & 3.85 & Trace & \\
\hline
\end{tabular}

(2)


Table 3. Stable isotope metrics for all sampling sites. $\mathrm{N}$ range is the range of $\delta^{15} \mathrm{~N}$ values at the site. $\mathrm{C}$ range is the range of $\delta^{13} \mathrm{C}$ values at the site. TA is total area of the convex hull polygon encompassing all individuals at the site. $\mathrm{CD}$ is the mean distance to centroid for the site. NND is the mean nearest neighbor distance for the site.

\begin{tabular}{cccccc}
\hline & & & & & \\
Site & N Range & C Range & TA & CD & NND \\
\hline 148 & 1.16 & 0.83 & 0.60 & 0.37 & 0.13 \\
151 & 1.86 & 4.27 & 3.05 & 0.87 & 0.35 \\
161 & 1.50 & 1.51 & 1.60 & 0.50 & 0.21 \\
167 & 1.73 & 1.91 & 1.91 & 0.47 & 0.13 \\
172 & 1.56 & 2.29 & 2.54 & 0.61 & 0.18 \\
180 & 1.17 & 4.32 & 4.26 & 0.86 & 0.24 \\
185 & 1.27 & 2.53 & 2.31 & 0.61 & 0.14 \\
188 & 1.42 & 2.21 & 1.96 & 0.51 & 0.18 \\
192 & 2.11 & 1.43 & 1.70 & 0.52 & 0.24 \\
198 & 1.96 & 2.10 & 2.15 & 0.62 & 0.25 \\
199 & 1.60 & 9.13 & 7.94 & 0.84 & 0.38 \\
205 & 1.22 & 2.26 & 2.16 & 0.60 & 0.24 \\
213 & 1.20 & 1.90 & 1.20 & 0.42 & 0.20 \\
217 & 2.20 & 2.44 & 2.86 & 0.58 & 0.19 \\
219 & 1.49 & 2.22 & 1.67 & 0.61 & 0.20 \\
222 & 2.12 & 2.23 & 2.95 & 0.64 & 0.22 \\
223 & 1.29 & 1.22 & 1.10 & 0.44 & 0.11 \\
227 & 2.00 & 1.61 & 2.34 & 0.57 & 0.11 \\
244 & 0.95 & 2.49 & 1.51 & 0.53 & 0.21 \\
251 & 1.46 & 1.96 & 1.56 & 0.48 & 0.16 \\
256 & 1.99 & 3.04 & 3.55 & 0.55 & 0.18 \\
\hline
\end{tabular}


Table 4. Bivariate correlations between all isotope metrics. Reported values are Pearson correlation coefficients. $\mathrm{N}$ range is the range of $\delta^{15} \mathrm{~N}$ values at the site. $\mathrm{C}$ range is the range of $\delta^{13} \mathrm{C}$ values at the site. TA is total area of the convex hull polygon encompassing all individuals at the site. $\mathrm{CD}$ is the mean distance to centroid for the site. NND is the mean nearest neighbor distance for the site.

\begin{tabular}{ccccc}
\hline & N Range & C Range & TA & CD \\
\hline C Range & 0.03 & - & - & - \\
TA & 0.23 & $0.95^{*}$ & - & - \\
CD & 0.18 & $0.77^{*}$ & $0.77^{*}$ & - \\
NND & 0.18 & $0.76^{*}$ & $0.68^{*}$ & $0.76^{*}$ \\
\hline$* \mathrm{p}<.05$ & & & &
\end{tabular}


Table 5. Factors found in principal components analysis.

\begin{tabular}{cccc}
\hline Component & Eigenvalue & Proportion & Cumulative \\
\hline 1 & 3.45 & 0.69 & 0.69 \\
2 & 0.98 & 0.20 & 0.89 \\
3 & 0.38 & 0.08 & 0.96 \\
4 & 0.17 & 0.03 & 0.99 \\
5 & 0.03 & 0.01 & 1.00 \\
\hline
\end{tabular}


Table 6. Results from principal components factor analysis used to form indicator of niche breadth used in structural equation modeling analyses. Loading values are rotated standardized factor loadings. $\mathrm{N}$ range is the range of $\delta^{15} \mathrm{~N}$ values at the site. $\mathrm{C}$ range is the range of $\delta^{13} \mathrm{C}$ values at the site. TA is total area of the convex hull polygon encompassing all individuals at the site. CD is the mean distance to centroid for the site. NND is the mean nearest neighbor distance for the site.

\begin{tabular}{cc}
\hline \multicolumn{2}{c}{ Factor Loading } \\
\hline N Range & 0.09 \\
C Range & 0.87 \\
TA & 0.90 \\
CD & 0.63 \\
NND & 0.39 \\
\hline
\end{tabular}


Table 7. A) Descriptive statistics for measured parameters included in structural equation models. Depth is depth of water at time of sampling. Herbivore density through detritivore density are the densities of each infauna functional group, calculated by dividing the number of individuals in a sample by the ash free dry mass of the periphyton sample. Periphyton TP is the total phosphorus in the periphyton at each site, reported as $\mu \mathrm{g} / \mathrm{g}$ dry mass. Percent edible periphyton is the percent of the periphyton that is diatom and green algae, found to be more palatable to consumers (Geddes \& Trexler, 2003). Conspecific density is the density of Eastern Mosquitofish at the collection site. Heterospecific density is the density of all other fish species at the site. B) Untransformed data.

\begin{tabular}{|c|c|c|c|}
\hline Variables & $\begin{array}{l}\text { Minimum } \\
\text { Value }\end{array}$ & $\begin{array}{l}\text { Maximum } \\
\text { Value }\end{array}$ & Mean $\pm \mathrm{SE}$ \\
\hline Depth (cm) & 30 & 93 & $59 \pm 3.3$ \\
\hline Omnivorous Infauna Density & 3.2 & 990 & $250 \pm 71$ \\
\hline Carnivorous Infauna Density & 0.0 & 580 & $67 \pm 28$ \\
\hline Herbivorous Infauna Density & 0.0 & 740 & $120 \pm 47$ \\
\hline Detritivorous Infauna Density & 0.0 & 170 & $28 \pm 8.6$ \\
\hline $\begin{array}{l}\text { Periphyton total phosphorus } \\
\left(\mu \mathrm{g} \mathrm{dry}^{-1}\right)\end{array}$ & 59 & 760 & $310 \pm 46$ \\
\hline$\%$ Edible Periphyton & 16 & 89 & $45 \pm 3.5$ \\
\hline $\begin{array}{l}\text { Conspecific density } \\
\left({\left.\text { number } \mathrm{m}^{-2}\right)}\right.\end{array}$ & 0.0 & 38 & $9.0 \pm 2.0$ \\
\hline $\begin{array}{l}\text { Heterospecific fish density } \\
\left(\text { number } \mathrm{m}^{-2}\right)\end{array}$ & 0.3 & 92 & $14 \pm 4.3$ \\
\hline
\end{tabular}


B)

Site Longitude Latitude $\begin{gathered}\text { Management } \\ \text { Area }\end{gathered}$ Depth DSD $\begin{gathered}\text { Periphyton } \\ \text { TP Edible } \\ \text { Periphyton }\end{gathered}$

\begin{tabular}{llllllll}
\hline 148 & 522064 & 2827223 & ENP & 42 & 178 & 279.2 & 47 \\
151 & 533946 & 2829412 & ENP & 38 & 174 & 58.9 & 16 \\
161 & 523007 & 2841503 & ENP & 50 & 179 & 93.8 & 40 \\
167 & 525989 & 2848534 & ENP & 61 & 160 & 243.3 & 48 \\
172 & 516901 & 2852383 & WCA3A & 93 & 2164 & 617.1 & 16 \\
180 & 552930 & 2866473 & WCA3A & 67 & 1653 & 495.9 & 59 \\
185 & 534712 & 2871878 & WCA3A & 62 & 1656 & 366.4 & 54 \\
188 & 526958 & 2875445 & WCA3A & 60 & 1655 & 134.8 & 48 \\
192 & 525654 & 2879218 & WCA3A & 51 & 212 & 267.1 & 54 \\
198 & 522838 & 2881704 & WCA3A & 55 & 274 & 187.4 & 37 \\
199 & 536594 & 2884041 & WCA3A & 64 & 1653 & 351.8 & 46 \\
205 & 546747 & 2891594 & WCA3A & 78 & 1657 & 690.4 & 26 \\
213 & 527780 & 2896559 & WCA3A & 51 & 267 & 92.2 & 45 \\
217 & 545499 & 2899782 & WCA3A & 59 & 212 & 372.8 & 59 \\
219 & 567320 & 2900755 & WCA3A & 47 & 510 & 425.4 & 31 \\
222 & 523268 & 2904903 & WCA3A & 30 & 183 & 133.1 & 58 \\
223 & 558362 & 2905685 & WCA2A & 80 & 266 & 158.0 & 34 \\
227 & 553918 & 2908303 & WCA2A & 79 & 183 & 132.2 & 46 \\
244 & 561491 & 2931042 & LOX & 50 & 1652 & 549.8 & 51 \\
251 & 529024 & 2830516 & ENP & 58 & 181 & 100.7 & 35 \\
256 & 531525 & 2849087 & ENP & 71 & 249 & 760.0 & 89 \\
\hline & & & & & & &
\end{tabular}




\begin{tabular}{|c|c|c|c|c|c|c|}
\hline Site & $\begin{array}{c}\text { Conspecific } \\
\text { density } \\
\left(\text { fish } / \mathrm{m}^{2}\right)\end{array}$ & $\begin{array}{l}\text { Heterospecific } \\
\text { fish density } \\
\quad\left(\mathrm{fish} / \mathrm{m}^{2}\right)\end{array}$ & $\begin{array}{l}\text { Omni- } \\
\text { vorous } \\
\text { Infauna } \\
\text { Density }\end{array}$ & $\begin{array}{l}\text { Carni- } \\
\text { vorous } \\
\text { Infauna } \\
\text { Density }\end{array}$ & $\begin{array}{l}\text { Herbi- } \\
\text { vorous } \\
\text { Infauna } \\
\text { Density }\end{array}$ & $\begin{array}{l}\text { Detriti- } \\
\text { vorous } \\
\text { Infauna } \\
\text { Density }\end{array}$ \\
\hline 148 & 2 & 2 & 472.4 & 94.0 & 282.9 & 38.8 \\
\hline 151 & 1 & 2 & 40.4 & 20.5 & 18.8 & 0.0 \\
\hline 161 & 3 & 0 & 74.6 & 13.3 & 141.3 & 3.1 \\
\hline 167 & 15 & 15 & 592.0 & 26.7 & 55.9 & 8.3 \\
\hline 172 & 4 & 12 & 6.9 & 9.0 & 0.0 & 2.7 \\
\hline 180 & 15 & 7 & 340.0 & 48.6 & 109.3 & 24.3 \\
\hline 185 & 25 & 22 & 68.4 & 165.6 & 75.6 & 61.2 \\
\hline 188 & 7 & 22 & 40.5 & 20.3 & 33.8 & 8.4 \\
\hline 192 & 6 & 15 & 990.6 & 139.2 & 233.4 & 70.0 \\
\hline 198 & 1 & 4 & 829.0 & 24.5 & 704.6 & 20.7 \\
\hline 199 & 9 & 15 & 3.2 & 2.1 & 0.0 & 0.0 \\
\hline 205 & 0 & 4 & 35.6 & 0.0 & 0.0 & 14.2 \\
\hline 213 & 4 & 12 & 65.7 & 15.2 & 30.3 & 0.0 \\
\hline 217 & 4 & 20 & 39.1 & 0.0 & 0.0 & 13.0 \\
\hline 219 & 5 & 1 & 140.7 & 9.6 & 0.0 & 5.8 \\
\hline 222 & 5 & 4 & 47.3 & 6.4 & 23.6 & 0.0 \\
\hline 223 & 12 & 8 & 30.7 & 15.4 & 10.2 & 46.1 \\
\hline 227 & 22 & 9 & 214.3 & 24.1 & 64.5 & 72.6 \\
\hline 244 & 10 & 29 & 986.0 & 580.1 & 741.6 & 31.3 \\
\hline 251 & 4 & 5 & 6.3 & 0.9 & 0.9 & 0.9 \\
\hline 256 & 38 & 92 & 191.6 & 189.3 & 16.1 & 166.5 \\
\hline
\end{tabular}


Table 8. Bivariate correlations. Displayed numbers are Pearson correlation coefficients from the SAS output. Depth is depth of water at time of sampling in $\mathrm{cm}$. Herbivore density through detritivore density are the densities of each infauna functional group, calculated by dividing the number of individuals in a sample by the ash free dry mass of the periphyton sample. Periphyton TP is the total phosphorus in the periphyton at each site, reported as $\mu \mathrm{g} / \mathrm{g}$ dry mass. Percent edible periphyton is the percent of the periphyton that is diatom and green algae, found to be more palatable to consumers (Geddes \& Trexler, 2003). Conspecific density is the density of Eastern Mosquitofish at the collection site, reported as fish $/ \mathrm{m}^{2}$. Heterospecific density is the density of other fish species at the site, reported as fish $/ \mathrm{m}^{2}$.

\begin{tabular}{|c|c|c|c|c|c|}
\hline Viche & Depth & DSD & $\begin{array}{c}\text { Periphyton } \\
\text { TP }\end{array}$ & $\begin{array}{c}\text { Omnivore } \\
\text { Infauna } \\
\text { Density }\end{array}$ & $\begin{array}{c}\text { Detritivore } \\
\text { Infauna } \\
\text { Density }\end{array}$ \\
\hline
\end{tabular}

\begin{tabular}{ccccccc}
\hline Depth & 0.32 & - & - & - & - & - \\
DSD & 0.16 & 0.38 & - & - & - & - \\
$\begin{array}{c}\text { Periphyton } \\
\text { TP }\end{array}$ & 0.35 & 0.44 & 0.51 & - & - & - \\
$\begin{array}{c}\text { Omnivore } \\
\text { Infauna } \\
\text { Density }\end{array}$ & -0.41 & -0.28 & -0.09 & 0.15 & - & - \\
$\begin{array}{c}\text { Detritivore } \\
\text { Infauna }\end{array}$ & -0.14 & 0.36 & 0.16 & 0.48 & 0.60 & - \\
$\begin{array}{c}\text { Density } \\
\text { Carnivore } \\
\text { Infauna }\end{array}$ & -0.14 & -0.16 & 0.08 & 0.16 & 0.70 & 0.57 \\
Density & & & & & &
\end{tabular}




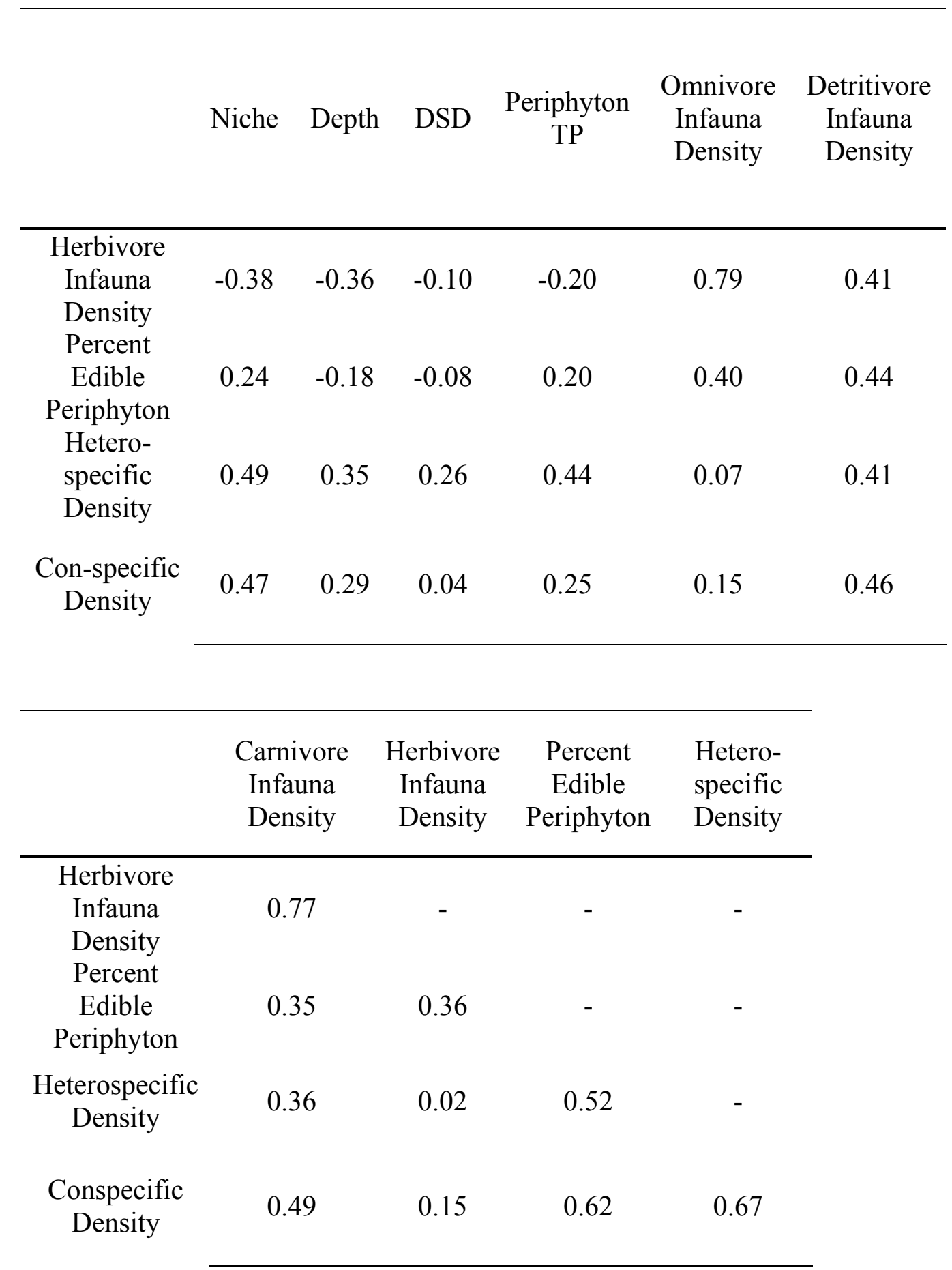




\section{FIGURE CAPTIONS}

Figure 1. Full model of predicted factors influencing isotopic niche breadth. Rectangles represent measured variables of interest. Lines represent predicted effects and point in direction of causation. Infauna are broken into functional groups but for ease of view single lines are used. However, in the SEM, separate paths were used between each infauna group and each variable. For the Dispersal model, the betas for the dotted lines are set at 0 (allowing for no direct effect of food availability on niche, nor for indirect effects of disturbance (depth or day since dry) on niche). For the Partitioning model, the beta for the dashed line is set at 0 (allowing for no direct effect of disturbance on niche).

Figure 2. Full model of predicted factors influencing isotopic niche breadth. Rectangles represent measured variables of interest. Lines represent predicted effects and point in the direction of hypothesized causation. Infauna are broken into functional groups but for ease of view, single lines are used between infauna and other variables. However, in the SEM, separate paths were used between each infauna group and each variable. The dotted lines indicate the indirect effects of depth on niche via fish densities and food availability. If the bold line has a larger effect on isotopic niche breadth, then the Dispersal hypothesis is supported. If the dotted lines have a larger effect, then the Partitioning hypothesis is supported.

Figure 3. Map of the study area in the Florida Everglades. Sampling sites indicated by points. 
Figure 4. Results of Full model with depth as the disturbance variable. Rectangles represent measured variables of interest and the $\mathrm{R}^{2}$ value is reported for each endogenous variable. Lines represent predicted effects, and point in direction of causation. Infauna are broken into functional groups but for ease of view single lines are used and each figure B-E highlights a single infauna functional group. Reported numbers next to lines are standardized betas. A shows betas for all paths unrelated to infauna. B shows the omnivorous infauna betas. $\mathrm{C}$ shows the herbivorous infauna betas. D shows the carnivorous infauna betas. E shows the detritivorous infauna betas. 
Figure 1.

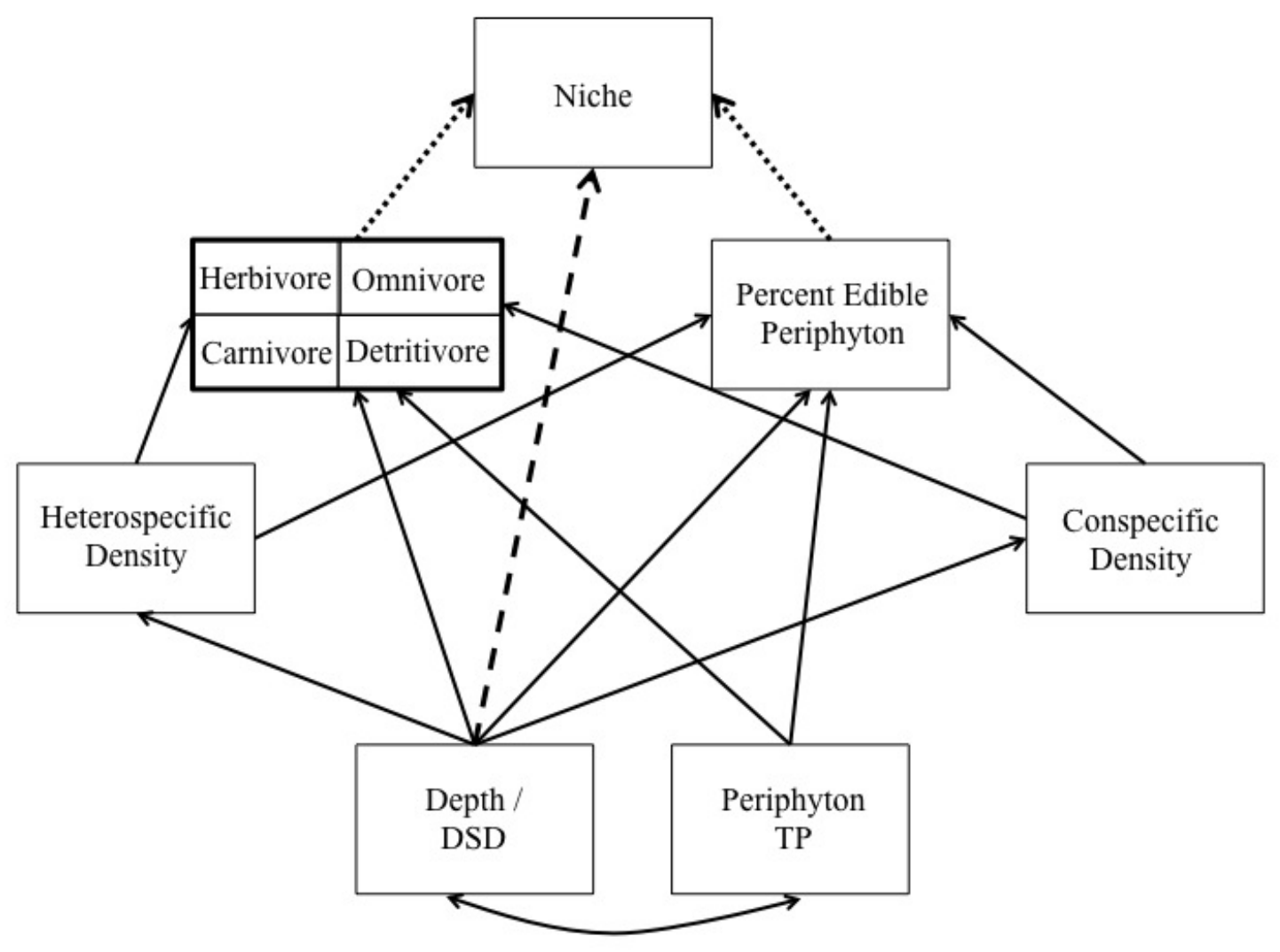


Figure 2.

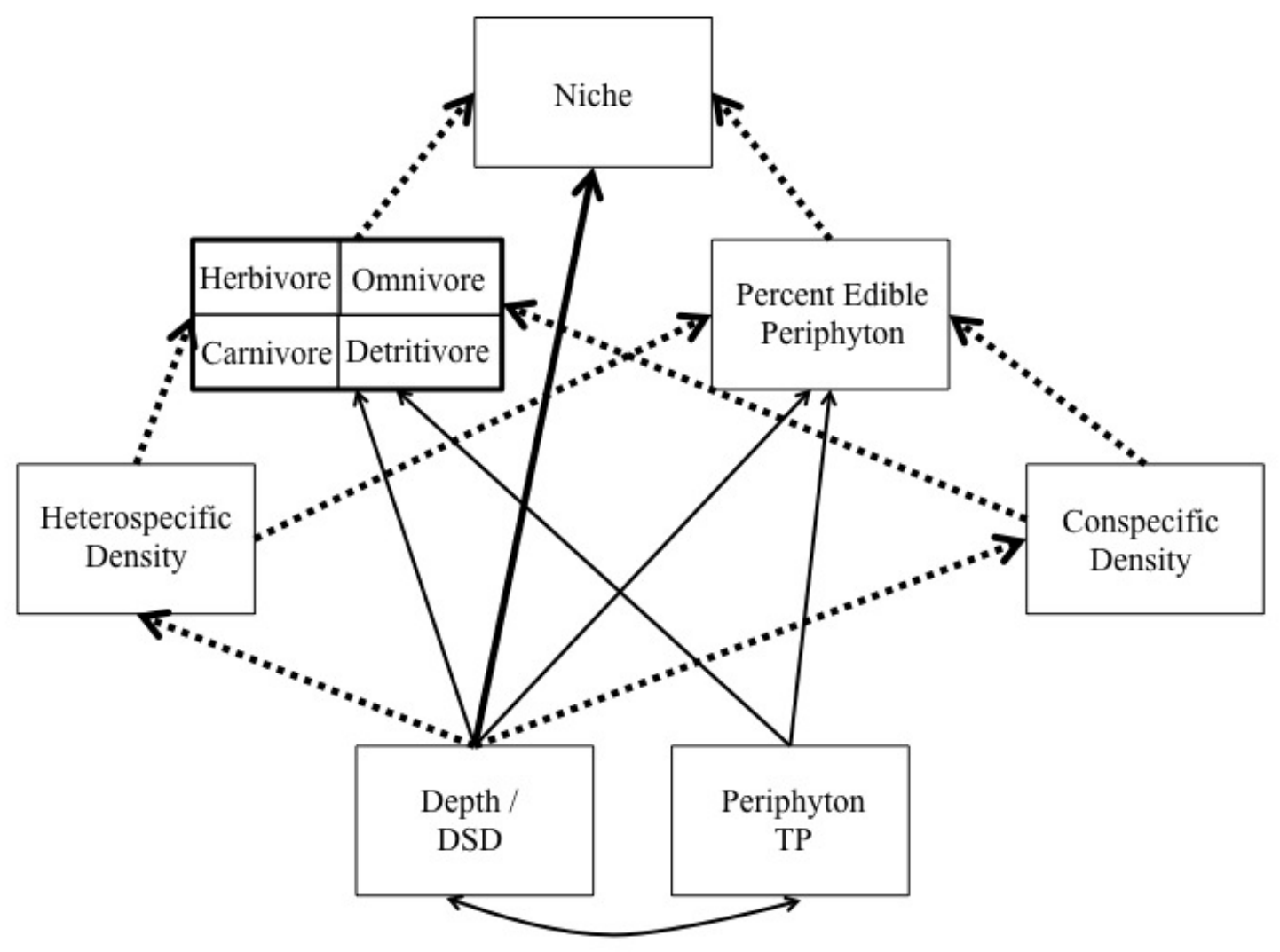


Figure 3.

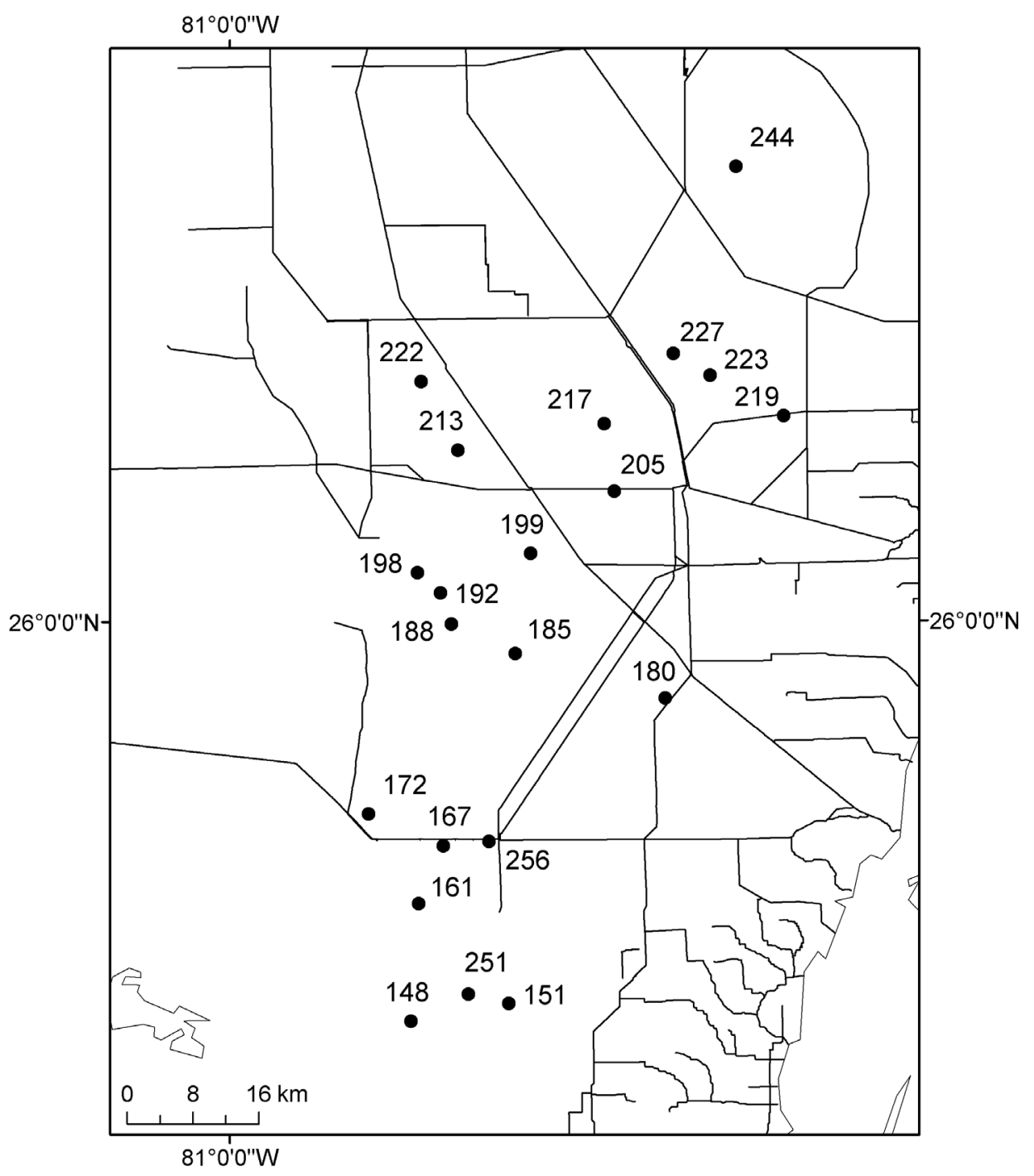


Figure 4.
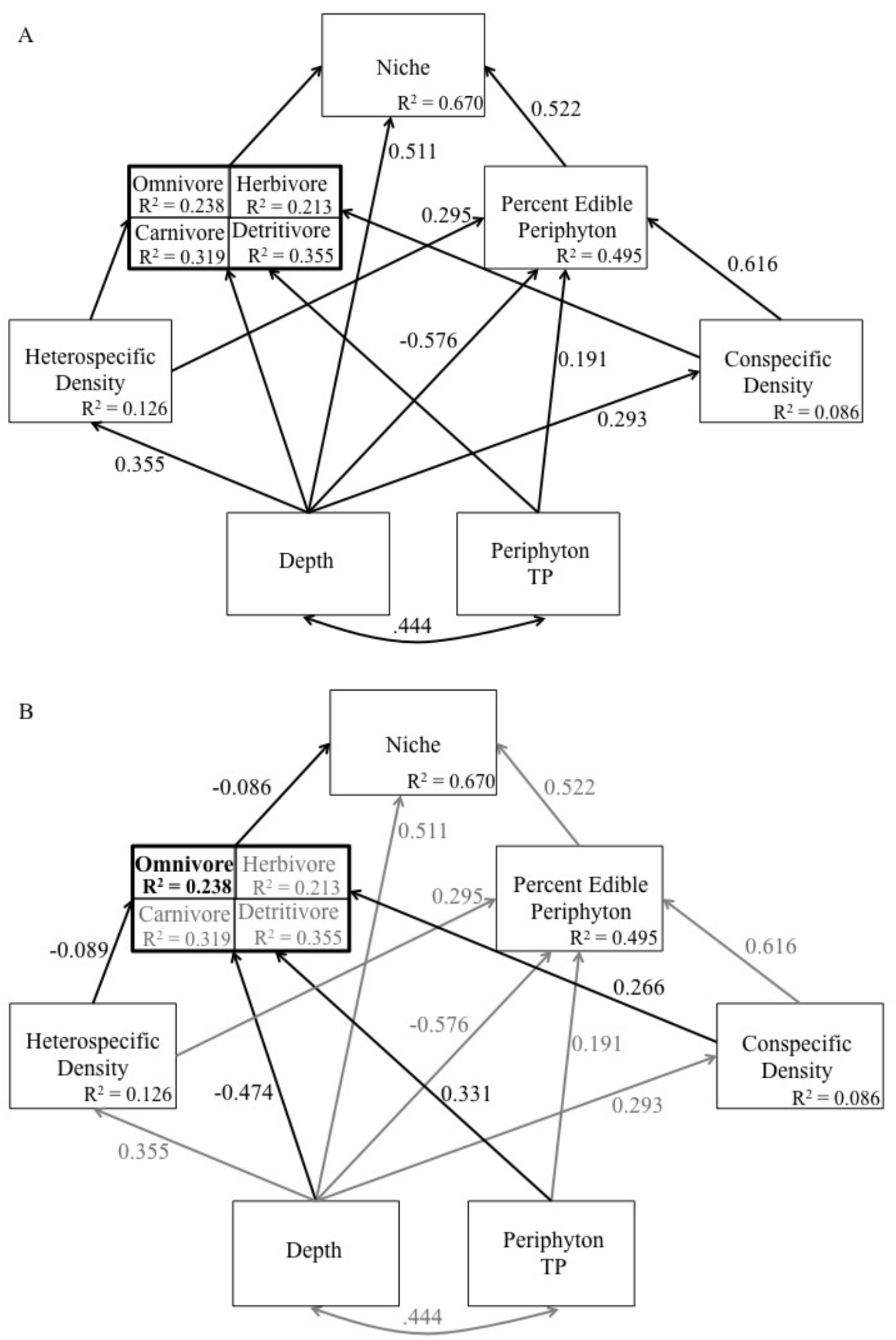

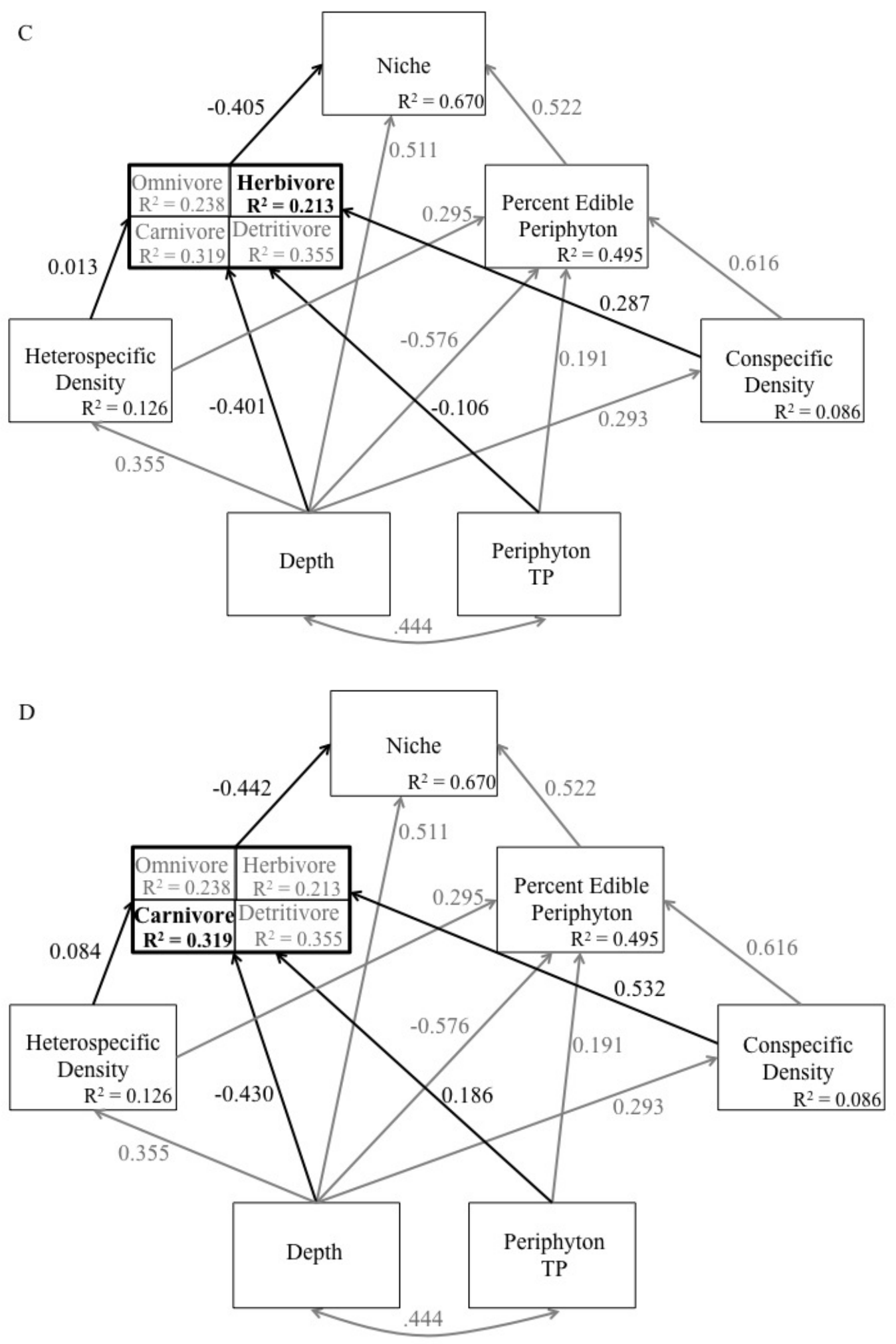


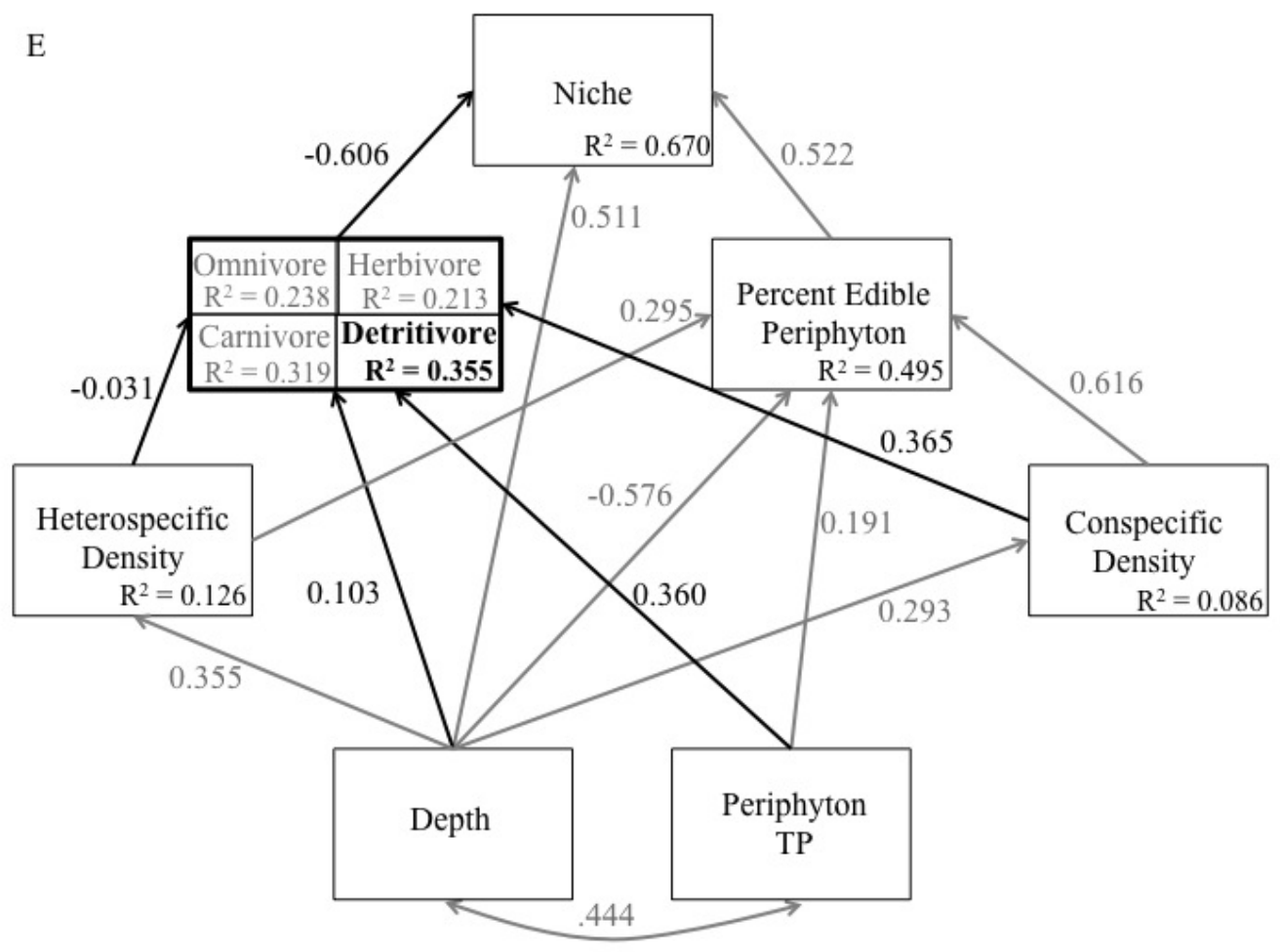

